\title{
Circulating microRNAs as Potential Biomarkers of Infectious Disease
}

\author{
Carolina N. Correia ${ }^{1}$, Nicolas C. Nalpas ${ }^{1 \dagger}$, Kirsten E. McLoughlin', John A. Browne', \\ Stephen V. Gordon ${ }^{2,3}$, David E. MacHugh ${ }^{1,3 *}$ and Ronan G. Shaughnessy ${ }^{2}$ \\ ${ }^{1}$ Animal Genomics Laboratory, UCD School of Agriculture and Food Science, University College Dublin, Dublin, Ireland, \\ ${ }^{2}$ UCD School of Veterinary Medicine, University College Dublin, Dublin, Ireland, ${ }^{3}$ University College Dublin, UCD Conway \\ Institute of Biomolecular and Biomedical Research, Dublin, Ireland
}

microRNAs (miRNAs) are a class of small non-coding endogenous RNA molecules that regulate a wide range of biological processes by post-transcriptionally regulating gene expression. Thousands of these molecules have been discovered to date, and multiple miRNAs have been shown to coordinately fine-tune cellular processes key to organismal development, homeostasis, neurobiology, immunobiology, and control of infection. The fundamental regulatory role of miRNAs in a variety of biological processes suggests that differential expression of these transcripts may be exploited as a novel source of molecular biomarkers for many different disease pathologies or abnormalities. This has been emphasized by the recent discovery of remarkably stable miRNAs in mammalian biofluids, which may originate from intracellular processes elsewhere in the body. The potential of circulating miRNAs as biomarkers of disease has mainly been demonstrated for various types of cancer. More recently, however, attention has focused on the use of circulating miRNAs as diagnostic/prognostic biomarkers of infectious disease; for example, human tuberculosis caused by infection with Mycobacterium tuberculosis, sepsis caused by multiple infectious agents, and viral hepatitis. Here, we review these developments and discuss prospects and challenges for translating circulating miRNA into novel diagnostics for infectious disease.

Keywords: biomarker, diagnostic, infection, transcriptomics, microRNA, serum, plasma

\section{WHAT MAKES A GOOD BIOMARKER?}

According to the working group of the National Institutes of Health Director's Initiative on Biomarkers and Surrogate Endpoints, a biomarker is "a characteristic that is objectively measured and evaluated as an indicator of normal biological processes, pathogenic processes, or pharmacologic responses to a therapeutic intervention" (1). A simpler but broader definition of biomarkers as objective, quantifiable characteristics of biological processes has also been emphasized by Strimbu and Tavel (2). The ideal biomarker has high specificity and sensitivity, is detectable by minimally invasive sampling procedures, and its concentration should be indicative of a disease state (1-5). Diagnostic biomarkers can be used to evaluate disease status, prognostic biomarkers are informative of disease outcome, and predictive biomarkers help determine treatment efficacy when experimental groups are compared to controls $(4,6)$.

In recent years, high-throughput sequencing (HTS) technologies have enabled simultaneous screening of thousands of potential transcriptional biomarkers, which facilitates both discovery of specific host disease expression biosignatures (7-9) and new insight on host-pathogen interaction and immunobiology (10-12). Host biomarkers may also help evaluate vaccine efficacy in both humans 
and domestic animals $(13,14)$, as well as provide information on the molecular mechanisms underlying latent infections (15) and drug resistance in pathogens (16).

\section{CANONICAL BIOGENESIS AND IMMUNOLOGICAL FUNCTIONS OF microRNAs (miRNAs)}

The role of miRNAs in post-transcriptional regulation of gene expression was discovered in 1993 through analyses of the lin-4 locus in the roundworm Caenorhabditis elegans. Two contemporaneous studies showed that an RNA transcript from lin-4 repressed translation of the lin-14 messenger RNA (mRNA), thereby exerting temporal developmental control on a diverse range of cell lineages $(17,18)$. Since then, it has been demonstrated that eukaryotic organisms contain hundreds to thousands of these small non-coding regulatory RNA molecules (19). Many miRNAs are evolutionarily conserved across divergent metazoan taxa $(20,21)$, highlighting the extensive roles that these small RNAs play in the regulatory networks and pathways governing complex biological processes such as cell fate specification, and innate and adaptive immunity (22-24).

Canonical biogenesis of miRNA in mammalian cells starts with transcription of a long RNA molecule called the primarymiRNA (pri-miRNA) by RNA polymerase II (25). Within the nucleus, pri-miRNA undergoes cleavage by the microprocessor complex, which consists of a Drosha ribonuclease III and the RNA-binding DGCR8 microprocessor complex subunit protein $(26,27)$. The intermediate product is a precursor-miRNA (premiRNA) hairpin of $\sim 70$ nucleotides in length that is transported to the cytoplasm by the exportin-5 protein (28). An additional cleavage occurs near the pre-miRNA terminal loop through the action of endoribonuclease Dicer (29). The final product is an 18-25 nucleotide double-stranded RNA with short 3' overhangs that binds to argonaute (AGO) proteins and is loaded into the RNA-induced silencing complex (RISC) by the RISC-loading complex (RLC), which is formed by endoribonuclease Dicer, RLC subunit TARBP2, and AGO1-4 proteins (30). One strand of the RNA duplex, the mature miRNA, remains within the RLC and is used as a guide by the RISC for complementary nucleotide base pairing with a target mRNA (31). The second strand is known as miRNA $^{*}$ (or passenger strand) and is normally degraded after its release from the RLC. Further details on canonical biogenesis (32) and the processes driving mature miRNA strand selection (33, 34) have been extensively reviewed elsewhere. The development of HTS technologies has facilitated high-resolution miRNAsequencing (miRNA-seq), revealing the existence of multiple functional mature variants that are termed isomiRs (35-37). In addition, non-canonical pathways have been identified as alternative mechanisms of miRNA biogenesis $(38,39)$.

Dysregulation of intracellular miRNAs during disease was first reported in 2002, with evidence that miR-15 and miR-16 were tumor suppressors for chronic lymphocyte leukemia (40). Shortly afterward, it was shown that higher let-7 expression levels were associated with a better prognosis for lung cancer survival (41). Notably, the cancer research literature has highlighted miRNAs as powerful classifiers for disease onset and patient survival (42-45), as well as tumor driver mutations (46-48). These, and several other studies that followed, laid the groundwork for research that focuses on exploring the potential of miRNAs as biomarkers and therapeutic gene targets.

In silico analyses suggest that at least two-thirds of mammalian mRNAs are regulated by miRNAs $(22,23,49)$; therefore, it is perhaps unsurprising that these non-coding transcripts have emerged as important molecular fine-tuners of the host immune response during infection (50-54). For example, multiple miRNAs are known to regulate the toll-like receptor 4 (TLR-4) pathway in the host innate immune response $(23,55,56)$ and are also essential for optimal $\mathrm{T}$ cell activation and differentiation (57-62). More specifically, mice lacking miR-155 show diminished immune responses against infections with Citrobacter rodentium (63), Salmonella typhimurium (64), and Listeria monocytogenes (65). miR-155 has also been found to be increased in peripheral monocytes of chronic hepatitis $\mathrm{C}(\mathrm{CHC})$-infected patients following in vitro stimulation with lipopolysaccharide (LPS) (66), and in murine bone marrow-derived macrophages stimulated with LPS plus interferon- $\gamma$ (IFN- $\gamma$ ) (67). miR-146 is another important miRNA that exhibits increased expression in immune cells following TLR activation by bacterial pathogens (68). Moreover, members of the miR-146 family were found to form distinct expression profiles in human monocyte-derived macrophage cells infected with Mycobacterium tuberculosis (69) and $M$. bovis-infected bovine alveolar macrophages (70). The immunoregulatory roles of miRNAs in different cells involved with the host response to bacterial infections has been comprehensively reviewed $(71,72)$.

Collectively, these studies highlight the importance of post-transcriptional regulation of gene expression mediated by intracellular miRNAs in mammalian infection and immunity processes. A growing number of public databases provide information on miRNA-disease relationships (73), and informative reviews on this topic have been published $(22,23,49,52,74)$.

\section{Circulating miRNAs}

So far, we have shown examples of intracellular miRNAs with immunological roles; however, there is a growing consensus that immune and non-immune cells routinely and actively release miRNAs into extracellular environments (75-77). Commonly associated with RNA-binding proteins, high-density lipoprotein particles or enclosed within lipid vesicles (Figure 1), miRNAs have been found to be extremely stable in extracellular fluids of mammals, such as blood plasma, serum, urine, saliva, and semen (78-80). miRNAs released by a human THP-1 monocyte cell line may be taken up by recipient cells in an alternative means of cell-to-cell communication (81). Wang and colleagues have shown that nucleophosmin, an RNA-binding protein involved with nuclear export of ribosomes, mediates export and protection of circulating miRNAs against degradation in several human cell lines (HepG2, A549, T98, and BSEA2B) immediately after serum deprivation, which is suggestive of an active response to stress (82). Active release of extracellular circulating miRNAs supports the hypothesis that they may act as "hormones" in cell-to-cell communication $(82,83)$. 


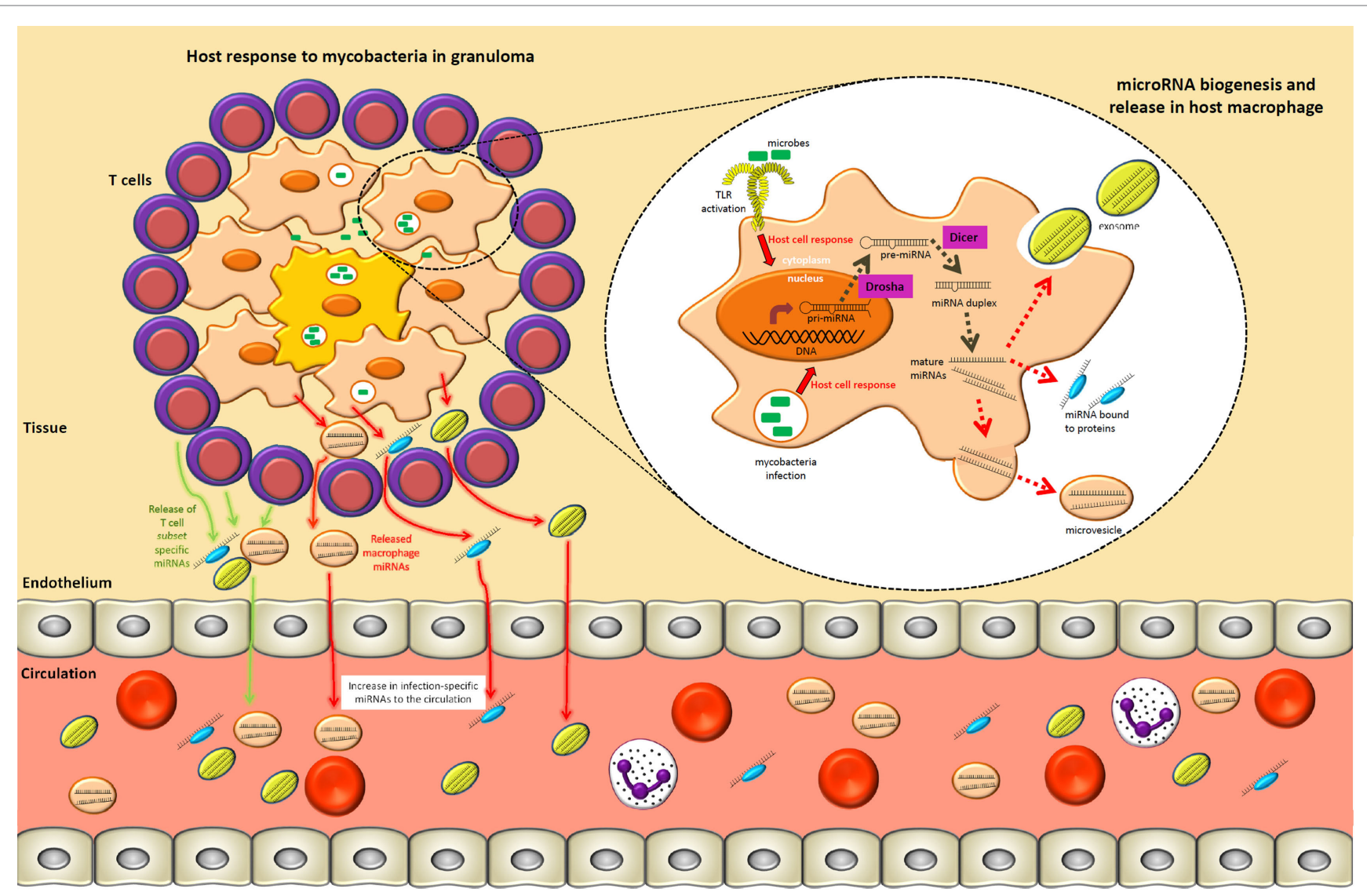

FIGURE 1 A tuberculosis lung granuloma demonstrates how specific circulating microRNAs (miRNAs) may arise during an infection process. Mycobacterial pathogen-associated molecular patterns are recognized by toll-like receptors (TLRs) and other pattern recognition receptors, which result in the upregulation of primary-miRNAs in macrophages. These transcripts are subsequently cleaved in the nucleus and cytoplasm by Drosha and Dicer, respectively, resulting in 21-25 nucleotide mature miRNAs that act to fine-tune intracellular immune processes. Specific pathways and components of the immune response may be regulated by different miRNA subsets. Concurrently, the surrounding T lymphocytes involved in granuloma formation/maintenance upregulate T cell subsetspecific miRNAs as a means of modulating the type of adaptive immune response. Mature miRNAs generated in macrophages and T cells may also be released into the extracellular environment within exosomes, heterogeneous microvesicles, or in association with high-density lipoprotein, LDL, or other protein complexes. Subsequently, by means not yet fully understood, these extracellular miRNAs move from local sites of infection to the circulatory system. This process can therefore give rise to infection-specific circulating miRNA expression signatures that can readily be accessed from multiple biological fluids (e.g., serum, plasma, or sputum).

Further work is required to fully understand how the release of extracellular miRNAs and uptake by target cell populations influences biomolecular signaling networks. Regardless of their precise functions, the main utility of miRNAs in the field of diagnostics and prognostics is based on the premise that different miRNA expression signatures are linked to different pathological states (Figure 1). With this in mind, it is noteworthy that a number of infectious diseases have been the focus of recent studies to assess circulating miRNAs as biomarkers.

\section{CHALLENGES FOR ACCURATE DETECTION OF CIRCULATING miRNAs IN BIOFLUIDS}

The observation that extracellular nucleic acids (both DNA and RNA) are present in vertebrate bodily fluids was first recorded almost 70 years ago (84), but their potential as biomarkers for disease states was not fully realized until the 1990s (85). In turn, detection of extracellular miRNAs was first reported in 2008 when placental miRNAs were observed in maternal plasma (86). In the same year, circulating miRNAs were also described in blood serum $(87,88)$ and plasma samples collected from cancer patients (88). In this regard, the potential of circulating miRNAs as non-invasive diagnostic and prognostic biomarkers of disease status in biological fluids was first realized in the field of cancer biology, particularly because techniques for cancer diagnosis and prognosis still primarily rely on invasive tissue biopsies (89-91), and the establishment of new circulating protein biomarkers has not been able to meet the demand (92). The marked stability of circulating miRNAs in body fluids, which are still viable after repeated cycles of freeze-thawing and long-term storage of frozen samples (88, 93-95), makes them attractive biomarker candidates for diagnosis or prognosis of complex diseases. However, the main challenges for profiling circulating miRNAs 
are biases introduced during pre-analytical and analytical steps that are described below.

\section{Biological Fluids and RNA Extraction}

Analysis of circulating miRNAs is normally performed on peripheral blood plasma or serum, and to a lesser extent on sputum, urine, breast milk, saliva, semen, and cerebrospinal fluid (CSF). The choice of starting material can significantly impact the expression profiles that are generated; in particular, because each biofluid can be enriched for a distinct set of miRNAs $(78,96,97)$.

The miRNA fraction in biological fluids typically represents a very low proportion of total RNA. Investigations using serum and plasma samples have demonstrated that different protocols for pre- and post-storage sample processing can impact the quality of subsequent RNA extraction $(96,98,99)$. For example, collection of peripheral blood in heparin-coated tubes can inhibit downstream laboratory steps that are based on polymerase chain reaction (PCR) protocols $(100,101)$. In addition, special attention is required to avoid contamination with intracellular miRNAs originating from blood components such as platelets and erythrocytes, which can introduce significant bias in circulating miRNA expression profiles $(96,98,99,102)$. It is also important that circulating miRNAs with low GC content are not lost when performing phenol-based RNA isolation, a problem that can be overcome by using small RNA extraction kits customized for specific biofluids (103).

\section{Expression Profiling Methods for Circulating miRNAs}

The biochemistry and molecular structure of miRNAs can cause difficulties for accurate transcriptional profiling and quantification $(104,105)$. Consequently, various established techniques for mRNA detection have been modified to improve miRNA detection, irrespective of tissue type (106-108).

Reverse transcription quantitative real-time PCR (RT-qPCR) is currently the most widely used method for miRNA profiling: it provides excellent sensitivity, high sample throughput, and the capacity for moderate multiplexing of targets (109). A number of strategies can be used with miRNA RT-qPCR, including (1) reverse transcription using stem loop primers as implemented in TaqMan $^{\text {TM }}$ MicroRNA Assays (110); (2) incorporation of locked nucleic acids (LNAs) (111) in primer sequences to reduce melting temperature $\left(T_{\mathrm{m}}\right)$ differences in primer-target duplexes, as used for miRCURY LNA ${ }^{\text {TM }}$ Universal RT microRNA PCR; and (3) approaches that enzymatically incorporate a poly(A) tail to miRNAs prior to the reverse transcription step, which facilitates hybridization with a poly(T) sequence linked to a universal reverse primer (109). Regardless of these technical developments, RT-qPCR-based methods cannot identify novel miRNAs and, importantly, special attention is required for the design of standardized internal controls $(104,112-114)$.

Hybridization-based methods normally rely on DNA capture probes that are immobilized on a microarray platform such that fluorescent signal intensities can be quantified to estimate expression of individual miRNAs. Commercially available and cost-effective microarray assays include miRCURY LNA ${ }^{\mathrm{TM}}$
microRNA Arrays (Exiqon), GeneChip ${ }^{\circledR}$ miRNA Arrays (Affymetrix), and SurePrint miRNA Microarrays (Agilent) (115). However, due to lower specificity and reduced dynamic range compared to other methods, microarrays often require additional validation via RT-qPCR $(116,117)$. A relatively new hybridization-based method that does not require a PCR amplification step or direct labeling of target miRNAs is the nCounter ${ }^{\circledR}$ miRNA Expression Assay developed by NanoString Technologies (118). This approach has comparable sensitivity to RT-qPCR, is high-throughput, and also facilitates multiplexing of up to 800 distinct miRNA variant targets in the same assay. miRNA profiling in serum (119), peripheral blood (120), and aortic tissue (121) provide examples of studies that have used this technology. However, like RT-qPCR, it is again important to note that hybridization-based profiling methods cannot be used to identify novel miRNA variants.

Unlike the methods discussed above, HTS technologies in the form of miRNA-seq can be used for discovery-focused global expression profiling of the whole miRNA transcriptome (miRNome) from a particular biological sample (122). In addition, miRNA-seq approaches can identify with high accuracy, novel mature miRNAs, sequence variants (specific isomiRs or particular miRNA family members), and also pre-miRNAs (37, $123,124)$. The rapid adoption of HTS for miRNA profiling has been driven by significant increases in sample throughput, a wide range of laboratory methods for different applications, and a thriving ecosystem of open-source software for data analysis and interpretation $(9,125,126)$. However, it is important to note that technical biases inherent to different sequencing technologies (e.g., Illumina ${ }^{\circledR}, \mathrm{ABI} S \mathrm{SLiD}{ }^{\circledR}$, and Ion Torrent ${ }^{\mathrm{TM}}$ ) may generate reads that are not bona fide miRNAs $(5,127,128)$.

Finally, in addition to established methods described here, emerging biosensor approaches for miRNA profiling have been reviewed in detail elsewhere and are beyond the scope this review (129).

\section{Data Normalization}

Transcriptomics experiments are characteristically "noisy," therefore, appropriate normalization is critical to minimize technical variation that may compromise interpretation of results. A range of methods have been successfully used for this purpose in mRNA and intracellular miRNA transcriptomics. Manufacturers' instructions for data normalization vary greatly depending on the platform used, and a consensus on how circulating miRNA data should be normalized is yet to emerge $(114,130)$.

There is significant debate concerning the optimal strategy for normalization of circulating miRNAs with RT-qPCR assays. Methods currently used include (1) normalization to small nucleolar RNAs as reference genes, (2) normalization to an external spike-in synthetic oligonucleotide, (3) normalization to specific miRNAs, and (4) the global mean normalization method (131). Most studies report the use of small nucleolar RNA genes as reference genes, such as the small nucleolar RNA, C/D box 44 gene (SNORD44), the small nucleolar RNA, C/D box 48 gene (SNORD48), and the RNA, U6 small nuclear 6, pseudogene (RNU6-6P). However, there is growing evidence that these genes may be unsuitable due to significant variability in expression 
among individual serum samples $(130,132,133)$. Use of a synthetic RNA spike-in as a reference gene has also been criticized because this method only accounts for specific components of technical variation introduced, for example, during RNA extraction or reverse transcription (134). When identifying circulating miRNAs to serve as reference genes, normally those that do not vary significantly among biological replicates are selected. Marabita et al. (114) advise caution when selecting endogenous reference controls and recommend the use of data-driven approaches for this purpose. The global mean normalization method does not require a reference gene and appears to be the most robust option but should only be applied when simultaneously profiling hundreds of miRNAs (131).

Conflicting reports on the efficiency of methods for statistical normalization are also problematic for miRNA-seq data. Tam and collaborators evaluated a range of available methods and recommended the use of trimmed mean of $M$-values (TMM) (135) and upper quartile scaling (136) for count normalization in comprehensive miRNA profiling studies (137). Conversely, Garmire and Subramaniam (138) did not support the use of TMM but strongly recommended the application of locally weighted regression (139, $140)$ or quantile normalization (QN) (141) instead. However, a parallel benchmarking study published soon afterward came to the opposite conclusion, recommending TMM over QN (142). Finally, a rebuttal to Garmire and Subramaniam highlighted several drawbacks with their data analysis and evaluation of the TMM method (143).

In summary, it is imperative that rigorous independent benchmarking studies are performed to systematically evaluate normalization methods proposed for miRNA profiling. With these challenges in mind, in the next section we review studies that have assessed the usefulness of circulating miRNAs as biomarkers for selected bacterial and viral infections.

\section{DIFFERENTIAL EXPRESSION OF CIRCULATING MIRNAS IN SPECIFIC INFECTIOUS DISEASES}

\section{Human Tuberculosis (TB)}

Human TB, caused by M. tuberculosis, continues to be a significant global health problem with 9.6 million new cases and 1.5 million deaths in 2014 (144). Classical methods for TB diagnostics in clinical settings include smear microscopy and mycobacterial culture. The former is the most used test in middle- and lowincome countries, but its sensitivity is highly variable (20-60\%), and the latter can take up to 8 weeks to yield results (145).

Diagnostic tests based on molecular methods represent a significant improvement in turnaround time and accuracy. Nonetheless, most molecular-based platform assays in use today are costly and have not been designed to be used in lower tiers of the health-care system $(145,146)$. According to Pai and Schito, one of the highest priorities for TB diagnostics is the development of a point-of-care non-sputum-based test capable of detecting all forms of TB, including extra pulmonary TB. Improved methods for distinction between active and latent TB are also urgently required (146).
Human TB was one of the first infectious diseases to be targeted for development of new diagnostics based on circulating serum or plasma miRNAs. Using a human miRNA microarray platform (Exiqon miRCURYTM LNA), Fu and colleagues were able to detect 92 differentially expressed miRNAs in serum from patients with active pulmonary TB compared to healthy individuals (147). However, it is important to note that an appropriate correction procedure for multiple statistical tests was not used in this study. Notwithstanding this, RT-qPCR validation demonstrated that circulating miR-93* and miR-29a were significantly upregulated in serum from the TB cases. In addition, miR-29a was also shown to be differentially expressed in sputum samples from TB patients compared to healthy controls (HC). A follow-up study using the same miRNA expression microarray, but with sputum samples from active pulmonary $\mathrm{TB}$ cases and $\mathrm{HC}$, also found that miR29a was upregulated in sputum from TB patients (148). However, inconsistencies were observed between the results obtained for circulating serum miRNAs by $\mathrm{Fu}$ and coworkers and those obtained by Yi and colleagues for sputum miRNAs. In particular, the 2 sets of 10 miRNAs that showed the most increased or decreased expression in TB patients were different for each body fluid $(147,148)$.

Parallel work using a different miRNA expression platform (Applied Biosystems TaqMan ${ }^{\circledR}$ Low Density Array Human MicroRNA Panel) and a comparable statistical approach identified a total of 97 differentially expressed miRNAs in serum samples from active pulmonary $\mathrm{TB}$ patients compared to $\mathrm{HC}$ (149). Following RT-qPCR validation and receiver operating characteristic (ROC) curve analysis, a panel of three miRNAs (miR-361-5p, miR-889, and miR-576-3p) was shown to differentiate TB patients from HC with moderate sensitivity and specificity. Further evaluation of the specificity of this panel of miRNAs for diagnosis of pulmonary TB was performed using RT-qPCR analysis of serum from pediatric patients infected with enterovirus, varicella-zoster virus, or Bordetella pertussis. All three miRNAs exhibited significant differences between the TB patient group and the other microbial infection groups, leading Qi and colleagues to propose this set of miRNAs as the starting point for a biosignature of human TB (149).

A comparative study of the diagnostic potential of a small panel of circulating serum miRNAs for pulmonary TB, lung cancer, and pneumonia was undertaken by Abd-El-Fattah et al. (150). Using RT-qPCR, these workers examined expression of four miRNAs (miR-21, miR-155, miR-182, and miR-197) in serum from pulmonary $\mathrm{TB}$, lung cancer, and pneumonia patient groups compared to a HC group. They observed that all four miRNAs were significantly differentially expressed between lung cancer patients and HC, three miRNAs (miR-21, miR-155, and miR-197) distinguished pneumonia patients from controls, but only one miRNA (miR-197) was significantly differentially expressed between the pulmonary TB group and the control group.

Two independent miRNA-seq studies of circulating serum miRNAs for diagnosis of active pulmonary TB revealed distinct panels of miRNAs as potential expression biomarkers of disease. The first study (151) showed that six circulating serum miRNAs (miR-378, miR-483-5p, miR-22, miR-29c, miR-101, and 
miR-320b) could serve as a distinct biosignature of pulmonary $\mathrm{TB}$ compared to $\mathrm{HC}$, and importantly, groups of pneumonia, lung cancer, and chronic obstructive pulmonary disease patients. Furthermore, ROC curve analysis demonstrated that a sixmiRNA biosignature could discriminate pulmonary TB patients from $\mathrm{HC}$ with a sensitivity of $95.0 \%$ and a specificity of $91.8 \%$ (151). In the second study (152), miRNA-seq was used to identify a total of 30 circulating serum miRNAs that were differentially expressed (24 increased and 6 decreased) in active pulmonary TB patients compared to 3 different control groups (latent TB infection, BCG-vaccinated, and HC). However, only 1 of these 30 circulating serum miRNAs (miR-22) was also detected in the earlier study by Zhang et al. (151).

Natural killer (NK) cells are effector lymphocytes that represent an important component of the innate immune system; they are able to rapidly target and kill virus-infected and tumorigenic cells in the absence of antibodies (153). Zhang et al. (154) observed decreased expression of circulating serum miR-155 in TB patients when compared to HC. From a functional perspective, levels of miRNA-155 were also inversely associated with cytotoxicity of NK cells isolated from the TB patients, which suggested that miR-155 may be used as an indicator of NK cell activity in TB patients (154).

The human TB studies described in this review have used serum and sputum as a source of circulating miRNAs and multiple transcriptomics technologies (miRNA-seq, microarray, and RT-qPCR) and data normalization methods, which together may contribute to the discordance among the results obtained by different researchers. Table 1 provides summary information on circulating miRNA biomarker studies for diagnosis and prognosis of human TB.

\section{Sepsis}

Sepsis is a subtype of systemic inflammatory response syndrome (SIRS), which is caused by an immune response triggered by various microbial infections. The causative agent is most commonly a bacterial pathogen, but it can also be triggered by infections involving fungi, viruses, or parasites (155). Sepsis is a major burden on health-care systems and of greatest concern in intensive care units (ICUs), where delayed diagnosis is a major cause of mortality. Consequently, in recent years there has been a concerted effort to develop circulating miRNA biomarkers for sepsis diagnosis and prognosis $(156,157)$.

Plasma levels of miR-150 have been shown to correlate with those of TNF- $\alpha$, IL-10, and IL-18, which are important immune response markers. More specifically, the ratio of miR-150/IL-18 has been suggested as a useful indicator of sepsis (158). miR-150 was also shown to exhibit increased expression in plasma from septic shock patients and was an independent predictor of mortality (159). Contrary to these results, circulating serum miR-150 levels could not be used to differentiate between critical illness patients and healthy individuals. However, although circulating miR-150 had no association with common markers of inflammation, it was independently correlated with unfavorable prognosis for patients (160).

It has previously been proposed that decreased expression of circulating miR-146a serves as an indicator of sepsis in both serum (161) and plasma (162). In addition, miR-223, which also exhibits decreased expression in plasma during sepsis, has been shown to display a greater capacity to distinguish sepsis from non-infectious SIRS than miR-146a (161). However, using more stringent statistical methods, a recent study demonstrated that miR-146a and miR-223 neither exhibited differential expression in plasma samples of sepsis and septic shock patients nor were they correlated with markers of inflammation, disease progression, or mortality (159). In addition, a comprehensive animal and clinical study has demonstrated that miR-223 serum levels do not correspond to the presence of sepsis in murine models or in a large cohort of ICU patients and do not reflect clinical outcome for critically ill patients (163). Taken together, these results constitute good evidence that circulating serum miR-223 cannot be used as a biomarker for sepsis.

TABLE 1 | Circulating microRNAs (miRNAs) profiled in selected human tuberculosis studies.

\begin{tabular}{|c|c|c|c|c|}
\hline Platform/assay & $\begin{array}{l}\text { Biological } \\
\text { fluid }\end{array}$ & $\begin{array}{l}\text { Notable miRNAs detected (arrows } \\
\text { indicate direction of expression) }\end{array}$ & Data normalization & Reference \\
\hline $\begin{array}{l}\text { miRCURY LNA array (Exiqon) } \\
\text { Gene Amp PCR system } 9700 \text { (Applied Biosystems) }\end{array}$ & $\begin{array}{l}\text { Serum and } \\
\text { sputum }\end{array}$ & $\operatorname{miR}-93^{\star} \uparrow, \operatorname{miR}-29 a \uparrow$ & $\begin{array}{l}\text { Median normalization } \\
\text { U6 snRNA }\end{array}$ & Fu et al. (147) \\
\hline $\begin{array}{l}\text { miRCURY LNA array (Exiqon) } \\
\text { GeneAmp PCR System } 9700 \text { (Applied Biosystems) }\end{array}$ & Sputum & $\begin{array}{l}\operatorname{miR}-3179 \uparrow, \operatorname{miR}-147 \uparrow, \operatorname{miR}-19 b-2^{*} \downarrow \\
\operatorname{miR}-29 a \uparrow\end{array}$ & $\begin{array}{l}\text { Median normalization } \\
\text { U6 snRNA }\end{array}$ & Yi et al. (148) \\
\hline $\begin{array}{l}\text { TaqMan Low Density array (Applied Biosystems) } \\
\text { TaqMan RT-qPCR (Applied Biosystems) }\end{array}$ & Serum & $\begin{array}{l}\operatorname{miR}-361-5 p \uparrow, m i R-889 \uparrow \\
\operatorname{miR}-576-3 p \uparrow\end{array}$ & $\begin{array}{l}\text { cel-miR-238 } \\
\text { miR-16 }\end{array}$ & Qi et al. (149) \\
\hline 7500 Real-Time PCR system (Applied Biosystems) & Serum & $\operatorname{miR}-197 \uparrow$ & SNORD68 & $\begin{array}{l}\text { Abd-El-Fattah et al. } \\
\text { (150) }\end{array}$ \\
\hline SYBR green RT-qPCR assay & Serum & $\begin{array}{l}\operatorname{miR}-378 \uparrow, m i R-483-5 p \uparrow, m i R-22 \uparrow \\
m i R-29 c \uparrow, m i R-101 \downarrow, m i R-320 b \downarrow\end{array}$ & $\begin{array}{l}\text { No information provided concerning } \\
\text { miRNA-sequencing normalization } \\
\text { method } \\
\text { miR-16 }\end{array}$ & Zhang et al. (151) \\
\hline $\begin{array}{l}\text { Solexa Small RNA-seq (Illumina) } \\
\text { TaqMan RT-qPCR (Applied Biosystems) }\end{array}$ & Serum & 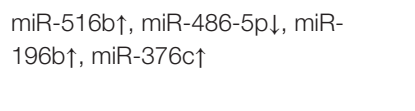 & $\begin{array}{l}\text { Total copy number of each sample } \\
\text { was normalized to } 100,000 \\
\text { cel-miR-238 }\end{array}$ & Zhang et al. (152) \\
\hline SYBR green RT-qPCR assay & Serum & 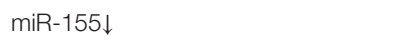 & U6 snRNA & Zhang et al. (154) \\
\hline
\end{tabular}


In a murine model of polymicrobial sepsis, circulating serum miR-133a, miR-155, miR-150, and miR-193b* displayed increased expression compared to baseline measurements (164). When extended to humans using large cohorts of ICU patients and HC, serum miR-133a also exhibited increased expression and displayed an increasing trend with disease severity. In addition, miR-133a was correlated not only with markers of inflammation and bacterial infection but also with renal and hepatic damage, cholestasis, and liver biosynthetic capacity. This work therefore supports further evaluation of miR-133a as a useful marker for the clinical state of critically ill patients (164). Another recent study using a murine model that was extended to human patients also revealed that miR-122 displayed increased expression independent of the presence of infection or sepsis in human ICU patients (165).

It has been shown that circulating serum miR-297 is upregulated in non-surviving sepsis patients when compared to survivors, whereas miR-574-5p is downregulated. In addition, the combination of sepsis stage, sequential organ failure assessment (SOFA) score and miR-574-5p expression was identified as an excellent predictor for patient survival from sepsis (166). Finally, another comprehensive study investigated aberrantly expressed serum miRNAs, demonstrating that a combination of four miRNAs (miR-15a, miR-16, miR-193b*, and miR483-5p) and three clinical indicators (SOFA score, acute physiology and chronic health evaluation score, and sepsis stage) can be used as a good predictor for mortality by sepsis (167).

Table 2 provides a summary of methodologies and notable miRNAs profiled for the sepsis studies discussed in this section.

\section{Viral Hepatitis \\ Hepatitis B}

According to the WHO, an estimated 240 million people are chronically infected with hepatitis $\mathrm{B}$ virus (HBV), and more than 686,000 people die every year due to complications of HBV infection (168). This viral infection attacks the liver and presents as acute or chronic disease. In comparison to other regions of the world, sub-Saharan Africa and East Asia show high endemicity of HBV infection (169). Additionally, chronic hepatitis B (CHB) infection is a major cause of liver cirrhosis and hepatocellular carcinoma (HCC), and reliable indicators of disease progression are urgently needed.

It has been shown that the occurrence of specific circulating miRNAs in blood serum of HBV-infected individuals increases with disease severity: 37 miRNAs in HC, 77 in chronic asymptomatic carriers, 101 in $\mathrm{CHB}$, and 135 in $\mathrm{HBV}$-associated acuteon-chronic liver failure (170). Circulating serum miR-210 (171) and miR-124 (172) are among the miRNAs implicated as being increased in conjunction with disease severity. Markers for liver fibrosis in HBV-infected patients have also been examined, with miR-345-3p, miR-371a-5p, and miR-2861 reported as positive indicators of fibrosis, whereas miR-486-3p and miR-497-5p exhibited lower expression at all stages of fibrosis when compared to non-fibrosis CHB patients (173).

Many published studies have suggested groups of circulating miRNAs that could distinguish CHB patients at early stages of HCC from those without the presence of cancer, such as plasma miR-122, miR-223, miR-26a, miR-27a, miR-192, miR-21, and miR-801 (174); plasma miR-28-5p, miR-30a-5p, miR-30e-3p, miR-378a-3p, miR-574-3p, and let-7c (175); serum miR-222, miR-223, and mir-21 (176); serum miR-206, miR-141-3p, miR433-3p, miR-1228-5p, miR-199a-5p, miR-122-5p, miR-192-5p, and miR-26a-5p (177); and exosomal serum miR-221, miR-222, miR-224, and miR-18a (178). Furthermore, miR-150 (179) and miR-18a (180) have been independently profiled in serum of HBV-HCC patients and found to exhibit significantly higher expression in these groups when compared to $\mathrm{CHB}$ samples.

An miRNA consistently reported in hepatitis infection studies is miR-122. Significant higher levels of this miRNA in plasma $(181,182)$ and serum $(170,183-185)$ samples of HBV-infected patients have been observed, and hence miR122 abundance has been suggested as a potential disease signature. miR-122 abundance was also positively correlated with current markers of viral activity in $\mathrm{HBV}$-infected patients $(170,185,186)$, but conflicting reports have been published regarding its correlation to degree of liver injury $(170,181,186)$. It is also important to note that miR-122 was significantly upregulated in a murine model for alcohol- and chemical-induced liver diseases (181) and non-alcoholic

TABLE 2 | Circulating microRNAs (miRNAs) profiled in selected sepsis studies.

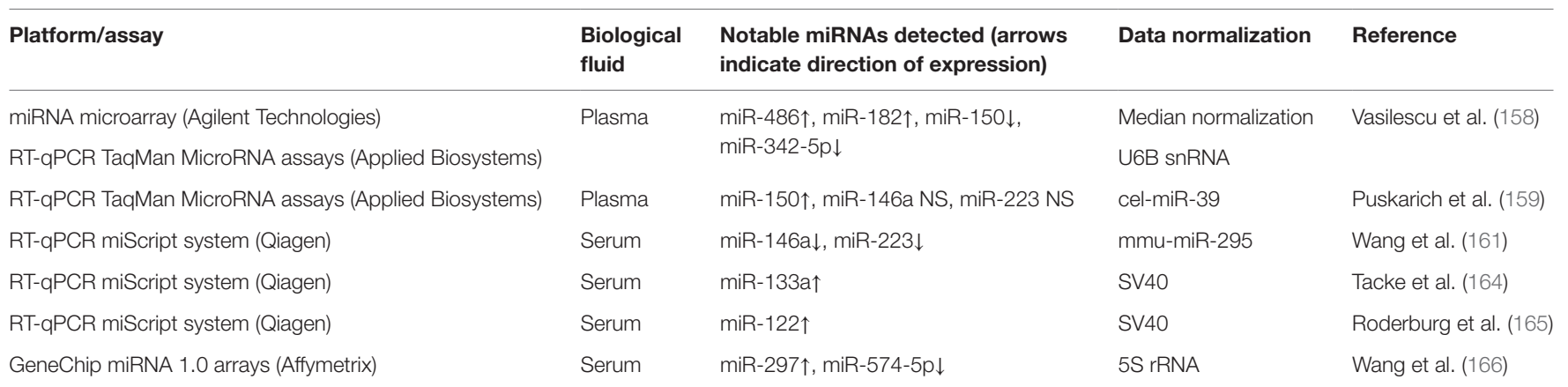

RT-qPCR miRcute (Tiangen Biotech Company)

Solexa Small RNA-seq (Illumina)

RT-qPCR TaqMan MicroRNA assays (Applied Biosystems)

Serum

miR-193b ${ }^{*} \uparrow, m i R-15 \uparrow, m i R-122 \uparrow$, miR- $\quad$ U6 snRNA

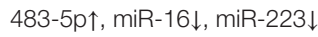

Wang et al. (167) 
steatohepatitis (184), which might implicate it as an unreliable biomarker.

miR-122 was also investigated as a component of miRNA panels that aim to offer a more robust biosignature of hepatitis B. For example, an assessment of $\mathrm{CHB}$ and healthy children during a period of 6 years revealed that miR-122-5p, miR-122-3p, miR$99 \mathrm{a}-5 \mathrm{p}$, and miR-125b-5p could be used to monitor pathological status $(187,188)$. Furthermore, the combination of miR-122, miR-let7c, miR-23b, and miR-150 was able to distinguish either HBV or occult HBV-infected patients from HC (189).

Other miRNAs have also been reported as potential biomarkers for HBV-infected patients: miR-375, miR-10a, miR-223, and miR-423 distinguished $\mathrm{HBV}$-infected patients from $\mathrm{HC}$, and the combination of miR-920 and miR-423 was able to differentiate between HBV- and hepatitis C virus (HCV)-infected individuals (190).

Table 3 provides a summary of methodologies and notable miRNAs profiled for the HBV infection studies discussed in this section.

\section{Hepatitis C}

Similar to HBV, the HCV can also give rise to both acute and chronic infection, possibly leading to progressive liver disease, cirrhosis, and hepatocellular cancer. Considering that miR-122 is a liver-specific miRNA (191), it is therefore not surprising that the majority of circulating miRNA studies have focused on miR-122 as a potential biomarker for hepatic pathologies. As previously observed in HBV studies, expression of circulating miR-122 has been found to be significantly higher in chronic HCV patients when compared to healthy cohorts (192-195). Panels of miRNAs that contained miR-122 also resulted in positive indicators for the presence of either CHC (66) or HCV (196). Positive correlation with current markers of HCV infection has been seen for miR-122 $(66,192)$ and miR-122-5p (196). However, miR-122 levels were also elevated in non-alcoholic fatty liver disease patients (193), and decreased levels were observed in one study with advanced stage fibrosis CHC patients (197).

Interestingly, high levels of serum miR-122 may predict favorable virological responses to therapy in pretreatment pegylated IFN alpha/ribavirin (pegIFN/RBV) patients of Asian ethnicity (198), but not for those of African and Caucasian ethnicities (199).

In a longitudinal study using plasma samples from non$\mathrm{HCV}$-infected injection drug users who eventually acquired the infection, miR-122 and miR-885-5p were increased in abundance during acute infection, whereas miR-494 and miR411 were decreased in expression. Also, in an independent cohort of individuals, all but miR-411 were validated (200). Furthermore, miR-122 and miR-885-5p levels remained elevated during viremia and returned to preinfection levels after infection resolution (200).

Considering other miRNA species, miR-571 has been associated with HCV-related cirrhosis progression (201); miR20a and miR-92a serum levels were elevated in HCV-infected fibrosis patients, and miR-92a expression was significantly reduced after infection resolution (202); circulating serum miR-320c, miR-134, and miR-483-5p were shown to be significantly increased in expression for $\mathrm{HCV}$-infected patients when compared to HC (203).

Early detection of HCC is also a major concern for $\mathrm{HCV}$ patients. Several published studies have investigated the usefulness of circulating miRNAs as a less-invasive diagnostic method. Serum levels of miR-16 were lower in HCC patients

TABLE 3 | Circulating microRNAs (miRNAs) profiled in selected hepatitis B studies.

\begin{tabular}{|c|c|c|c|c|}
\hline Platform/assay & $\begin{array}{l}\text { Biological } \\
\text { fluid }\end{array}$ & $\begin{array}{l}\text { Notable miRNAs detected } \\
\text { (arrows indicate direction of } \\
\text { expression) }\end{array}$ & Data normalization & Reference \\
\hline RT-qPCR TaqMan MicroRNA assays (Applied Biosystems) & Serum & $\operatorname{miR}-210 \uparrow$ & cel-miR-39 & Song et al. (171) \\
\hline miRNA microarray (Agilent Technologies) & Plasma & 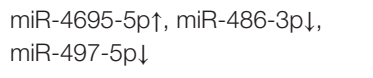 & Quantile normalization & Zhang et al. (173) \\
\hline $\begin{array}{l}\text { SYBR Green I-based RT-qPCR with individual miRNA-specific } \\
\text { primers (Applied Biosystems) }\end{array}$ & Plasma & $\operatorname{miR}-122 \uparrow$ & U6 snRNA & Zhang et al. (181) \\
\hline Thunderbird SYBR qPCR mix (Toyobo, Japan) & Plasma & $\operatorname{miR}-122 \uparrow$ & No information provided & Zhang et al. (182) \\
\hline TaqMan probe-based RT-qPCR (Applied Biosystems) & Serum & 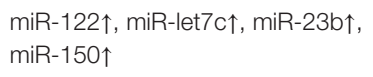 & Plant MIR-168 & Chen et al. (189) \\
\hline $\begin{array}{l}\text { Solexa Small RNA-seq (lllumina) } \\
\text { TaqMan probe-based RT-qPCR (Applied Biosystems) }\end{array}$ & Serum & 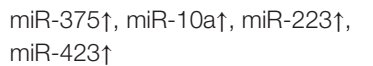 & Plant MIR-168 & Li et al. (190) \\
\hline
\end{tabular}


when compared to either HCV (204) or chronic liver diseases (CLD) groups (205). miR-21 serum levels were elevated in CHC and CHC-associated HCC patients, in comparison with HC (206). In plasma samples, miR-21 levels were also significantly higher for HCC patients when compared to chronic hepatitis (B or C types) and healthy groups (207). Lastly, miR-199a exhibited moderate power to distinguish HCC patients from CLD groups (205).

Although there are many published studies describing the use of circulating miRNAs as biomarkers of hepatitis B (Table 3) or hepatitis C (Table 4), specificity and lack of independent validation remain significant problems hindering adoption of circulating miRNAs as useful biomarkers for hepatitis.

\section{Other Infectious Diseases \\ Pertussis}

Pertussis, also known as whooping cough, is a respiratory infection caused by $B$. pertussis. A panel of five circulating miRNAs was observed to be upregulated in serum samples from infected patients (miR-202, miR-342-5p, miR-206, miR-487b, and miR-576-5p), showing high sensitivity and specificity for differentiation of pertussis patients and HC. In addition, analysis of this miRNA panel in samples from patients with a range of other microbial infections ( $M$. tuberculosis, enterovirus, varicellazoster virus, mumps virus, and measles virus) demonstrated that the expression signature for pertussis disease was distinct and unambiguous (208).

\section{Human Immunodeficiency Virus (HIV)-Associated Neurological Disorders (HAND)}

Cognitive, motor, and behavioral impairments that affect individuals infected with the HIV are collectively referred to as HAND $(209,210)$. An miRNA pairwise approach has demonstrated the potential use of two pairs of plasma miRNAs as biomarkers for cognitive-impaired HIV-positive individuals: miR-495-3p in combination with let-7b-5p, miR-151a-5p, or miR-744-5p; and miR-376a-3p/miR-16-5p (211).

It is recognized that early detection of HAND would facilitate better treatment choices and fewer sequelae caused by neuronal damage. However, this phenomenon has been difficult to investigate in patient cohorts; therefore, it has required the use of animal models such as the macaque (Macaca nemestrina) simian immunodeficiency virus (SIV) model of HIV (212). A combination of six circulating plasma miRNAs (miR-125b, miR-34a, miR-21, miR-1233, miR-130b, and miR-146a) could be used to predict the development of central nervous system disease in a macaque/SIV model, when animal samples from pre- and postinfection were compared to HC (212). Expression of circulating miRNAs in CSF of HIV-encephalitis (HIVE) patients has been compared to HIV-positive patients without signs of HAND, and also to HIV-negative individuals. Overall, decreased expression of miRNAs was observed between HIV-positive and HIV-negative groups, whereas between HIVE and HIV-negative no changes in expression were observed. General increased expression was only observed when HIVE and HIV-positive groups were compared, with miR-19b-2*, miR-937, and miR-362-5p displaying the largest fold changes (213).

\section{Hand, Foot and Mouth Disease (HFMD)}

Human enterovirus 71 (EV71) and coxsackievirus A16 (CVA16) are the most common pathogens responsible for HFMD. More than 500,000 cases, including 176 fatal ones, have been reported in China since an outbreak in 2008 (214). Levels of eight circulating serum miRNAs (miR-148a, miR-143, miR-324-3p, miR-628-3p, miR-206, miR-140-5p, miR-455-5p, and miR-362-3p) were significantly higher in sera of patients with enteroviral infections (215). The combination of six miRNAs (miR-148a, miR-143, miR324-3p, miR-628-3p, miR-140-5p, and miR-362-3p) generated

TABLE 4 | Circulating microRNAs (miRNAs) profiled in selected hepatitis C studies.

\begin{tabular}{|c|c|c|c|c|}
\hline Platform/assay & $\begin{array}{l}\text { Biological } \\
\text { fluid }\end{array}$ & $\begin{array}{l}\text { Notable miRNAs detected } \\
\text { (arrows indicate direction of } \\
\text { expression) }\end{array}$ & Data normalization & Reference \\
\hline RT-qPCR TaqMan MicroRNA assays (Applied Biosystems) & Serum & $\mathrm{miR}-122 \uparrow, \mathrm{miR}-34 \mathrm{a} \uparrow, \mathrm{miR}-16 \uparrow$ & cel-miR-238 & Cermelli et al. (193) \\
\hline RT-qPCR TaqMan MicroRNA assays (Applied Biosystems) & Serum & $\operatorname{miR}-122 \uparrow, \operatorname{miR}-192 \uparrow$ & $\begin{array}{l}\text { Normalized for initial serum } \\
\text { input }\end{array}$ & van der Meer et al. (194) \\
\hline RT-qPCR TaqMan MicroRNA assays (Applied Biosystems) & Serum & $\operatorname{miR}-122 \uparrow, \operatorname{miR}-155 \uparrow$ & cel-miR-39 & Bala et al. (66) \\
\hline $\begin{array}{l}\text { miRNA PCR arrays } \\
\text { Individual RT-qPCR assays }\end{array}$ & Serum & 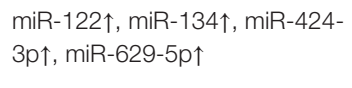 & U6 snRNA & Zhang et al. (196) \\
\hline RT-qPCR TaqMan MicroRNA assays & Serum & $\operatorname{miR}-122 \uparrow$ & cel-miR-39 & Su et al. (198) \\
\hline $\begin{array}{l}\text { TaqMan RT-qPCR OpenArray chips } \\
\text { Individual TaqMan RT-qPCR assays }\end{array}$ & Plasma & 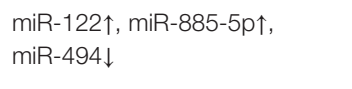 & $\begin{array}{l}\text { Quantile normalization } \\
\text { ath-miR-159a }\end{array}$ & El-Diwany et al. (200) \\
\hline miRNA microarray (Agilent) & Serum & $\begin{array}{l}\text { miR-134 }, \text { miR-320c } \uparrow \\
m i R-483-5 p \uparrow\end{array}$ & Percentile shift normalization & Shwetha et al. (203) \\
\hline
\end{tabular}


a biosignature that could distinguish enteroviral patients and HC. In addition, a panel comprising miR-143, miR-324-3p, and miR-545 had moderate ability in discriminating patients infected with CVA16 from those with EV71 (215). Circulating exosomal miRNAs (miR-671-5p, miR-16-5p, and miR-150-3p) have also been observed to be differentially expressed in serum samples from both mild and extremely severe cases of HFMD when compared to that from healthy individuals (216). Lastly, a signature of eight miRNAs (miR-494, miR-29b-3p, miR-551a, miR-606, miR876-5p, miR-30c-5p, miR-221-3p, and miR-150-5p) was identified in serum of children infected with EV71 (119). Furthermore, the results presented by Wang and collaborators suggested that upregulation of miR-876-5p is a specific response to severe EV71 infection.

\section{Varicella}

Varicella, commonly known as chickenpox, is caused by the varicella-zoster virus. Aberrant serum miRNA expression in non-vaccinated children that contracted varicella revealed a panel of five miRNAs (miR-197, miR-629, miR-363, miR-132, and miR-122) that could differentiate, with moderate sensitivity and specificity, varicella patients from $\mathrm{HC}$, and also varicella patients from patients with three other microbial infections $(B$. pertussis, measles virus, and enterovirus) (217).

\section{Influenza}

Influenza A viruses are the causative agents of influenza in birds and mammals. A panel of 14 circulating miRNAs was observed to be aberrantly expressed in whole blood samples from patients infected with the H1N1 strain of influenza virus A (218). Further analyses showed that six of these miRNAs (miR-1260, miR-335*, miR-664, miR-26a, miR-576-3p, and miR-628-3p) had similar expression signatures in human A549 and Madin-Darby canine kidney (MDCK) cells infected with $\mathrm{H} 1 \mathrm{~N} 1$ in vitro. In addition, examination of MDCK supernatant exosomes indicated that only miR-576-3p was not detectable (218). Also, evaluation of serum samples from influenza $\mathrm{A} / \mathrm{H} 1 \mathrm{~N} 1$ patients demonstrated that critically ill patients exhibited elevated expression of miR150 , when compared to those presenting a milder form of the disease (219).

Avian influenza A (H7N9) has been recently detected in China and was associated with fatal cases. Circulating serum miR-17,

\begin{tabular}{|c|c|c|c|c|c|}
\hline Pathology & Platform/assay & $\begin{array}{l}\text { Biological } \\
\text { fluid }\end{array}$ & $\begin{array}{l}\text { Notable miRNAs detected (arrows } \\
\text { indicate direction of expression) }\end{array}$ & $\begin{array}{l}\text { Data } \\
\text { normalization }\end{array}$ & Reference \\
\hline Pertussis (human) & $\begin{array}{l}\text { RT-qPCR TaqMan Array Human miRNA } \\
\text { panel (Applied Biosystems) }\end{array}$ & Serum & $\begin{array}{l}\operatorname{miR}-202 \uparrow, m i R-342-5 p \uparrow \operatorname{miR}-206 \uparrow \\
m i R-487 b \uparrow, m i R-576-5 p \uparrow\end{array}$ & cel-miR-238 & Ge et al. (208) \\
\hline Varicella (human) & $\begin{array}{l}\text { RT-qPCR TaqMan Array Human miRNA } \\
\text { panel (Applied Biosystems) }\end{array}$ & Serum & $\begin{array}{l}\operatorname{miR}-197 \uparrow, \operatorname{miR}-629 \uparrow, \operatorname{miR}-363 \uparrow, \mathrm{miR}- \\
132 \uparrow, \operatorname{miR}-122 \uparrow\end{array}$ & cel-miR-238 & Qi et al. (217) \\
\hline Influenza H1N1 (human) & RT-qPCR TaqMan & Whole blood & $\begin{array}{l}\operatorname{miR}-1260 \uparrow, m i R-335 \uparrow^{*}, m_{i R}-664 \uparrow, m i R- \\
26 a \downarrow, m i R-576-3 p \uparrow, m i R-628-3 p \downarrow\end{array}$ & $\begin{array}{l}\text { Normalized to } \\
\text { endogenous } \\
\text { controls and the } \\
\text { spike-in control } \\
\text { 18S rRNA }\end{array}$ & $\begin{array}{l}\text { Tambyah et al. } \\
(218)\end{array}$ \\
\hline $\begin{array}{l}\text { Influenza A/H1N1 virus } \\
\text { (human) }\end{array}$ & $\begin{array}{l}\text { RT-qPCR TaqMan Array Human miRNA } \\
\text { panel (Applied Biosystems) }\end{array}$ & Serum & $\operatorname{miR}-150 \uparrow$ & U6 snRNA & $\begin{array}{l}\text { Moran et al. } \\
(219)\end{array}$ \\
\hline $\begin{array}{l}\text { Avian Influenza A H7N9 } \\
\text { (human) }\end{array}$ & $\begin{array}{l}\text { RT-qPCR TaqMan Array Human miRNA } \\
\text { panel (Applied Biosystems) }\end{array}$ & Serum & $\begin{array}{l}\operatorname{miR}-17 \uparrow, \operatorname{miR}-20 a \uparrow, \operatorname{miR}-106 a \uparrow, \\
\operatorname{miR}-376 c \uparrow\end{array}$ & cel-miR-238 & Zhu et al. (220) \\
\hline $\begin{array}{l}\text { Hand, foot and mouth } \\
\text { disease (human) }\end{array}$ & $\begin{array}{l}\text { RT-qPCR TaqMan Array Human miRNA } \\
\text { panel (Applied Biosystems) }\end{array}$ & Serum & $\begin{array}{l}\operatorname{miR}-148 a \uparrow, m i R-143 \uparrow, m i R-324- \\
3 p \uparrow, m i R-628-3 p \uparrow, m i R-140-5 p \uparrow, \\
m i R-362-3 p \uparrow\end{array}$ & cel-miR-238 & Cui et al. (215) \\
\hline $\begin{array}{l}\text { Hand, foot and mouth } \\
\text { disease (human) }\end{array}$ & $\begin{array}{l}\text { miRNA microarrays (Agilent Technologies) } \\
\text { RT-qPCR }\end{array}$ & $\begin{array}{l}\text { Serum } \\
\text { exosomes }\end{array}$ & 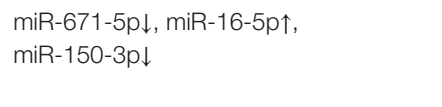 & $\begin{array}{l}\text { Standard Agilent } \\
\text { normalization } \\
\text { miR-642a-3p }\end{array}$ & Jia et al. (216) \\
\hline \multirow[t]{2}{*}{$\begin{array}{l}\text { Hand, foot and mouth } \\
\text { disease (human) }\end{array}$} & $\begin{array}{l}\text { nCounter miRNA Expression assays } \\
\text { (NanoString) }\end{array}$ & Serum & 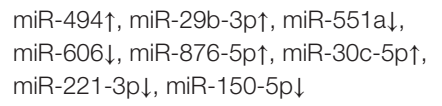 & $\begin{array}{l}\text { Geometric } \\
\text { mean of top } 100 \\
\text { miRNAs }\end{array}$ & $\begin{array}{l}\text { Wang et al. } \\
(119)\end{array}$ \\
\hline & $\begin{array}{l}\text { RT-qPCR TaqMan assays (Applied } \\
\text { Biosystems) }\end{array}$ & & & U6 snRNA & \\
\hline $\begin{array}{l}\text { Human immunodeficiency } \\
\text { virus (HIV)-associated } \\
\text { neurological disorders } \\
\text { (human) }\end{array}$ & RT-qPCR microRNA panels (Exiqon) & Plasma & $\begin{array}{l}\operatorname{miR}-151 a-5 p \uparrow, \operatorname{miR}-194-5 p \uparrow \\
m i R-19 b-1-5 p \uparrow\end{array}$ & $\begin{array}{l}\text { miR-23a-3p and } \\
\text { miR-23b-3p }\end{array}$ & Kadri et al. (211) \\
\hline HIV-encephalitis (human) & RT-qPCR microRNA panels (Exiqon) & $\begin{array}{l}\text { Cerebrospinal } \\
\text { fluid }\end{array}$ & $m i R-19 b-2^{*} \uparrow, m i R-937 \uparrow, m i R-362-5 p \uparrow$ & $\begin{array}{l}\text { miR-622 and } \\
\text { miR-1266 }\end{array}$ & $\begin{array}{l}\text { Pacifici et al. } \\
(213)\end{array}$ \\
\hline $\begin{array}{l}\text { Staphylococcus aureus- } \\
\text { induced mastitis (bovine) }\end{array}$ & TruSeq small RNA sequencing (Illumina) & $\begin{array}{l}\text { Bovine milk } \\
\text { exosomes }\end{array}$ & $\operatorname{miR}-142-5 p \uparrow, m i R-223 \uparrow$ & $\begin{array}{l}\text { Upper quantile } \\
\text { normalization }\end{array}$ & Sun et al. (222) \\
\hline
\end{tabular}


miR-20a, miR-106a, and miR-376c were significantly increased in expression for patients compared to healthy individuals (220).

\section{Infectious Diseases of Veterinary Importance}

Staphylococcus aureus is most common causative agent of contagious bovine mastitis, which represents a significant economic burden to the dairy industry (221). Evaluation of milk exosomes from S. aureus-infected Holstein cows indicated miR-142-5p and miR-223 as potential biomarkers for this infection in mammary glands (222).

It is important to note that the use of age-matched subjects may be critical for experiments designed to detect circulating miRNAs as biomarkers of infection in young animals. Consequently, results from such experiments should be interpreted with caution since they may be confounded by expression of miRNAs associated with developmental processes. This issue has been addressed recently by Farrell and colleagues using serum samples collected from calves at preinfection and 6 months after infection with Mycobacterium avium subspecies paratuberculosis (MAP). Expression profiling of circulating miRNAs via miRNA-seq showed differential expression of miR-205 and miR-432, but a signature of infection could not be identified (223). On the other hand, analysis of biobanked bovine serum samples from experimental infections with MAP (stored at $-20^{\circ} \mathrm{C}$ for $10-15$ years) revealed that the circulating miRNA profile was remarkably similar in composition to the profile from fresh sera $(<1$ year at $\left.-80^{\circ} \mathrm{C}\right)(94)$. miRNAs have also been shown to correlate with season (summer, after the calves were born; fall, at weaning; and the following spring) when serum from Mycoplasma bovis-infected calves was profiled, but similar to the MAP studies described above a strong signature of infection was not observed (224).

Studies focusing on miRNAs in animals of veterinary relevance are still relatively few and most are restricted to cellular miRNAs. However, unlike human studies where cohort sizes may be limited, where age, gender, and ethnicity profiles may differ, and where patient histories cannot be readily assessed, veterinary studies can leverage sophisticated experimental designs that may help uncover nuances of circulating miRNA expression profiles that better represent disease status in infected individuals.

A summary of the results obtained for studies discussed in Sections "Other Infectious Diseases" and "Infectious Diseases of Veterinary Importance" are presented in Table 5.

\section{REFERENCES}

1. Biomarkers Definitions Working Group. Biomarkers and surrogate endpoints: preferred definitions and conceptual framework. Clin Pharmacol Ther (2001) 69:89-95. doi:10.1067/mcp.2001.113989

2. Strimbu K, Tavel JA. What are biomarkers? Curr Opin HIV AIDS (2010) 5:463-6. doi:10.1097/COH.0b013e32833ed177

3. Etheridge A, Lee I, Hood L, Galas D, Wang K. Extracellular microRNA: a new source of biomarkers. Mutat Res (2011) 717:85-90. doi:10.1016/ j.mrfmmm.2011.03.004

4. Nalejska E, Maczynska E, Lewandowska MA. Prognostic and predictive biomarkers: tools in personalized oncology. Mol Diagn Ther (2014) 18:273-84. doi:10.1007/s40291-013-0077-9

\section{CONCLUSION AND FUTURE PERSPECTIVES FOR CIRCULATING mIRNAS AS BIOMARKERS OF INFECTION}

Robustness to adverse sampling and storage conditions, especially for body fluids, is the most compelling reason that circulating miRNAs have significant potential as ancillary minimally invasive biomarkers for a wide range of pathologies. Thus far, research work has focused on identifying biomarkers and/or biosignatures for several diseases; however, studies that use systematic validation and independent confirmation are still relatively rare. In this regard, inconsistent results have been described across multiple studies that may be attributable to underpowered experimental design, lack of validation in subjects with pathologies that elicit similar immune responses, absence of standardized reference genes for normalization, and inappropriate statistical methodologies (e.g., no correction for multiple testing). Therefore, throughout the workflow, from sample collection and handling to the downstream bioinformatics, standardization of analytical methods will be key to establishing circulating miRNAs as robust and reliable biomarkers in clinical settings.

\section{AUTHOR CONTRIBUTIONS}

$\mathrm{CC}$ and $\mathrm{RS}$ reviewed the relevant literature and drafted the initial manuscript. CC, RS, and DM prepared the figure. NN, KM, and JB contributed additional material to the manuscript. DM and SG supervised the study and oversaw preparation, editing, and revision of the manuscript. All the authors have read and approved the final manuscript.

\section{ACKNOWLEDGMENTS}

The authors wish to thank Damien Farrell, David Magee, Kate Killick, and Kevin Rue-Albrecht for fruitful discussions.

\section{FUNDING}

The study was founded by the Brazilian Science Without Borders Programme (CAPES grant no. BEX-13070-13-4), Science Foundation Ireland (grant nos. SFI/08/IN.1/B2038 and SFI/15/ IA/3154), and the Department of Agriculture, Food and the Marine (grant no. RSF11/S/141 - ICONMAP).

5. Buschmann D, Haberberger A, Kirchner B, Spornraft M, Riedmaier I, Schelling G, et al. Toward reliable biomarker signatures in the age of liquid biopsies - how to standardize the small RNA-Seq workflow. Nucleic Acids Res (2016) 44:5995-6018. doi:10.1093/nar/gkw545

6. Ballman KV. Biomarker: predictive or prognostic? JClin Oncol (2015) 33:3968-71. doi:10.1200/JCO.2015.63.3651

7. Ramilo O, Allman W, Chung W, Mejias A, Ardura M, Glaser C, et al. Gene expression patterns in blood leukocytes discriminate patients with acute infections. Blood (2007) 109:2066-77. doi:10.1182/blood-2006-02002477

8. Mejias A, Ramilo O. Transcriptional profiling in infectious diseases: ready for prime time? J Infect (2014) 68(Suppl 1):S94-9. doi:10.1016/j.jinf.2013. 09.018 
9. Weiner J, Kaufmann SH. High-throughput and computational approaches for diagnostic and prognostic host tuberculosis biomarkers. Int J Infect Dis (2017) (in press). doi:10.1016/j.ijid.2016.10.017

10. Mohr S, Liew CC. The peripheral-blood transcriptome: new insights into disease and risk assessment. Trends Mol Med (2007) 13:422-32. doi:10.1016/ j.molmed.2007.08.003

11. Blankley S, Berry MP, Graham CM, Bloom CI, Lipman M, O’Garra A. The application of transcriptional blood signatures to enhance our understanding of the host response to infection: the example of tuberculosis. Philos Trans R Soc Lond B Biol Sci (2014) 369:20130427. doi:10.1098/rstb. 2013.0427

12. Chaussabel D. Assessment of immune status using blood transcriptomics and potential implications for global health. Semin Immunol (2015) 27:58-66. doi:10.1016/j.smim.2015.03.002

13. Kaufmann SH, Fortune S, Pepponi I, Ruhwald M, Schrager LK, Ottenhoff TH. TB biomarkers, TB correlates and human challenge models: new tools for improving assessment of new TB vaccines. Tuberculosis (Edinb) (2016) 99(Suppl 1):S8-11. doi:10.1016/j.tube.2016.05.010

14. Vordermeier HM, Jones GJ, Buddle BM, Hewinson RG, VillarrealRamos B. Bovine tuberculosis in cattle: vaccines, diva tests, and host biomarker discovery. Annu Rev Anim Biosci (2016) 4:87-109. doi:10.1146/ annurev-animal-021815-111311

15. Esterhuyse MM, Weiner J III, Caron E, Loxton AG, Iannaccone M, Wagman $\mathrm{C}$, et al. Epigenetics and proteomics join transcriptomics in the quest for tuberculosis biomarkers. MBio (2015) 6:e1187-1115. doi:10.1128/mBio. 01187-15

16. Wallis RS, Peppard T. Early biomarkers and regulatory innovation in multidrug-resistant tuberculosis. Clin Infect Dis (2015) 61(Suppl 3):S160-3. doi:10.1093/cid/civ612

17. Lee RC, Feinbaum RL, Ambros V. The C. elegans heterochronic gene lin-4 encodes small RNAs with antisense complementarity to lin-14. Cell (1993) 75:843-54. doi:10.1016/0092-8674(93)90529-Y

18. Wightman B, Ha I, Ruvkun G. Posttranscriptional regulation of the heterochronic gene lin-14 by lin- 4 mediates temporal pattern formation in C. elegans. Cell (1993) 75:855-62. doi:10.1016/0092-8674(93)90530-4

19. Kozomara A, Griffiths-Jones S. miRBase: annotating high confidence microRNAs using deep sequencing data. Nucleic Acids Res (2014) 42:D68-73. doi:10.1093/nar/gkt1181

20. Wheeler BM, Heimberg AM, Moy VN, Sperling EA, Holstein TW, Heber S, et al. The deep evolution of metazoan microRNAs. Evol Dev (2009) 11:50-68. doi:10.1111/j.1525-142X.2008.00302.x

21. Berezikov E. Evolution of microRNA diversity and regulation in animals. Nat Rev Genet (2011) 12:846-60. doi:10.1038/nrg3079

22. O'Connell RM, Rao DS, Chaudhuri AA, Baltimore D. Physiological and pathological roles for microRNAs in the immune system. Nat Rev Immunol (2010) 10:111-22. doi:10.1038/nri2708

23. O'Neill LA, Sheedy FJ, McCoy CE. microRNAs: the fine-tuners of toll-like receptor signalling. Nat Rev Immunol (2011) 11:163-75. doi:10.1038/ nri2957

24. Shenoy A, Blelloch RH. Regulation of microRNA function in somatic stem cell proliferation and differentiation. Nat Rev Mol Cell Biol (2014) 15:565-76. doi:10.1038/nrm3854

25. Lee Y, Kim M, Han J, Yeom KH, Lee S, Baek SH, et al. microRNA genes are transcribed by RNA polymerase II. EMBO J (2004) 23:4051-60. doi:10.1038/ sj.emboj.7600385

26. Lee Y, Ahn C, Han J, Choi H, Kim J, Yim J, et al. The nuclear RNase III Drosha initiates microRNA processing. Nature (2003) 425:415-9. doi:10.1038/ nature01957

27. Han J, Lee Y, Yeom KH, Kim YK, Jin H, Kim VN. The Drosha-DGCR8 complex in primary microRNA processing. Genes Dev (2004) 18:3016-27. doi:10.1101/gad.1262504

28. Lund E, Guttinger S, Calado A, Dahlberg JE, Kutay U. Nuclear export of microRNA precursors. Science (2004) 303:95-8. doi:10.1126/science. 1090599

29. Zhang HD, Kolb FA, Brondani V, Billy E, Filipowicz W. Human Dicer preferentially cleaves dsRNAs at their termini without a requirement for ATP. EMBO J (2002) 21:5875-85. doi:10.1093/emboj/cdf582

30. Chendrimada TP, Gregory RI, Kumaraswamy E, Norman J, Cooch N, Nishikura K, et al. TRBP recruits the Dicer complex to Ago2 for microRNA processing and gene silencing. Nature (2005) 436:740-4. doi:10.1038/ nature 03868

31. Lewis BP, Shih IH, Jones-Rhoades MW, Bartel DP, Burge CB. Prediction of mammalian microRNA targets. Cell (2003) 115:787-98. doi:10.1016/ s0092-8674(03)01018-3

32. Schwarz DS, Hutvagner G, Du T, Xu Z, Aronin N, Zamore PD. Asymmetry in the assembly of the RNAi enzyme complex. Cell (2003) 115:199-208. doi:10.1016/s0092-8674(03)00759-1

33. Kim Y, Yeo J, Lee JH, Cho J, Seo D, Kim JS, et al. Deletion of human tarbp2 reveals cellular microRNA targets and cell-cycle function of TRBP. Cell Rep (2014) 9:1061-74. doi:10.1016/j.celrep.2014.09.039

34. Wilson RC, Tambe A, Kidwell MA, Noland CL, Schneider CP, Doudna JA. Dicer-TRBP complex formation ensures accurate mammalian microRNA biogenesis. Mol Cell (2015) 57:397-407. doi:10.1016/j.molcel.2014.11.030

35. Morin RD, O'Connor MD, Griffith M, Kuchenbauer F, Delaney A, Prabhu $\mathrm{AL}$, et al. Application of massively parallel sequencing to microRNA profiling and discovery in human embryonic stem cells. Genome Res (2008) 18:610-21. doi:10.1101/gr.7179508

36. Neilsen CT, Goodall GJ, Bracken CP. IsomiRs - the overlooked repertoire in the dynamic microRNAome. Trends Genet (2012) 28:544-9. doi:10.1016/ j.tig.2012.07.005

37. Guo L, Chen F. A challenge for miRNA: multiple isomiRs in miRNAomics. Gene (2014) 544:1-7. doi:10.1016/j.gene.2014.04.039

38. Okamura K, Hagen JW, Duan H, Tyler DM, Lai EC. The mirtron pathway generates microRNA-class regulatory RNAs in Drosophila. Cell (2007) 130:89-100. doi:10.1016/j.cell.2007.06.028

39. Ruby JG, Jan CH, Bartel DP. Intronic microRNA precursors that bypass Drosha processing. Nature (2007) 448:83-6. doi:10.1038/nature05983

40. Calin GA, Dumitru CD, Shimizu M, Bichi R, Zupo S, Noch E, et al. Frequent deletions and down-regulation of micro-RNA genes miR15 and miR16 at $13 q 14$ in chronic lymphocytic leukemia. Proc Natl Acad Sci U S A (2002) 99:15524-9. doi:10.1073/pnas.242606799

41. Takamizawa J, Konishi H, Yanagisawa K, Tomida S, Osada H, Endoh H, et al. Reduced expression of the let-7 microRNAs in human lung cancers in association with shortened postoperative survival. Cancer Res (2004) 64:3753-6. doi:10.1158/0008-5472.CAN-04-0637

42. Bianchi F, Nicassio F, Marzi M, Belloni E, Dall'Olio V, Bernard L, et al. A serum circulating miRNA diagnostic test to identify asymptomatic high-risk individuals with early stage lung cancer. EMBO Mol Med (2011) 3:495-503. doi:10.1002/emmm.201100154

43. Boeri M, Verri C, Conte D, Roz L, Modena P, Facchinetti F, et al. microRNA signatures in tissues and plasma predict development and prognosis of computed tomography detected lung cancer. Proc Natl Acad Sci U S A (2011) 108:3713-8. doi:10.1073/pnas.1100048108

44. Ciesla M, Skrzypek K, Kozakowska M, Loboda A, Jozkowicz A, Dulak J. microRNAs as biomarkers of disease onset. Anal Bioanal Chem (2011) 401:2051-61. doi:10.1007/s00216-011-5001-8

45. Tan X, Qin W, Zhang L, Hang J, Li B, Zhang C, et al. A 5-microRNA signature for lung squamous cell carcinoma diagnosis and hsa-miR-31 for prognosis. Clin Cancer Res (2011) 17:6802-11. doi:10.1158/1078-0432.CCR-11-0419

46. Gasparini P, Cascione L, Landi L, Carasi S, Lovat F, Tibaldi C, et al. microRNA classifiers are powerful diagnostic/prognostic tools in ALK-, EGFR-, and KRAS-driven lung cancers. Proc Natl Acad Sci U S A (2015) 112:14924-9. doi:10.1073/pnas.1520329112

47. Du F, Yuan P, Zhao ZT, Yang Z, Wang T, Zhao JD, et al. A miRNA-based signature predicts development of disease recurrence in HER2 positive breast cancer after adjuvant trastuzumab-based treatment. Sci Rep (2016) 6:33825. doi:10.1038/srep33825

48. Kurozumi S, Yamaguchi Y, Kurosumi M, Ohira M, Matsumoto H, Horiguchi J. Recent trends in microRNA research into breast cancer with particular focus on the associations between microRNAs and intrinsic subtypes. J Hum Genet (2017) 62:15-24. doi:10.1038/jhg.2016.89

49. Baltimore D, Boldin MP, O'Connell RM, Rao DS, Taganov KD. microRNAs: new regulators of immune cell development and function. Nat Immunol (2008) 9:839-45. doi:10.1038/ni.f.209

50. Pauley KM, Chan EK. microRNAs and their emerging roles in immunology. Ann N Y Acad Sci (2008) 1143:226-39. doi:10.1196/annals.1443.009

51. Lu LF, Liston A. microRNA in the immune system, microRNA as an immune system.Immunology (2009) 127:291-8. doi:10.1111/j.1365-2567.2009.03092.x 
52. O'Connell RM, Rao DS, Baltimore D. microRNA regulation of inflammatory responses. Annu Rev Immunol (2012) 30:295-312. doi:10.1146/ annurev-immunol-020711-075013

53. Chen CZ, Schaffert S, Fragoso R, Loh C. Regulation of immune responses and tolerance: the microRNA perspective. Immunol Rev (2013) 253:112-28. doi:10.1111/imr.12060

54. Zhu S, Pan W, Qian Y. microRNA in immunity and autoimmunity. J Mol Med (Berl) (2013) 91:1039-50. doi:10.1007/s00109-013-1043-z

55. Yang L, Seki E. Toll-like receptors in liver fibrosis: cellular crosstalk and mechanisms. Front Physiol (2012) 3:138. doi:10.3389/fphys.2012.00138

56. He X, Jing Z, Cheng G. microRNAs: new regulators of toll-like receptor signalling pathways. Biomed Res Int (2014) 2014:945169. doi:10.1155/2014/ 945169

57. Liston A, Linterman M, Lu LF. microRNA in the adaptive immune system, in sickness and in health. J Clin Immunol (2010) 30:339-46. doi:10.1007/ s10875-010-9378-5

58. Dooley J, Linterman MA, Liston A. microRNA regulation of T-cell development. Immunol Rev (2013) 253:53-64. doi:10.1111/imr.12049

59. Jeker LT, Bluestone JA. microRNA regulation of T-cell differentiation and function. Immunol Rev (2013) 253:65-81. doi:10.1111/imr.12061

60. Podshivalova K, Salomon DR. microRNA regulation of T-lymphocyte immunity: modulation of molecular networks responsible for T-cell activation, differentiation, and development. Crit Rev Immunol (2013) 33:435-76. doi:10.1615/CritRevImmunol.2013006858

61. Tang X, Tang R, Xu Y, Wang Q, Hou Y, Shen S, et al. microRNA networks in regulatory T cells. J Physiol Biochem (2014) 70:869-75. doi:10.1007/ s13105-014-0348-x

62. Amado T, Schmolka N, Metwally H, Silva-Santos B, Gomes AQ. Crossregulation between cytokine and microRNA pathways in $\mathrm{T}$ cells. Eur J Immunol (2015) 45:1584-95. doi:10.1002/eji.201545487

63. Clare S, John V, Walker AW, Hill JL, Abreu-Goodger C, Hale C, et al. Enhanced susceptibility to Citrobacter rodentium infection in microRNA-155-deficient mice. Infect Immun (2013) 81:723-32. doi:10.1128/IAI. 00969-12

64. Rodriguez A, Vigorito E, Clare S, Warren MV, Couttet P, Soond DR, et al. Requirement of bic/microRNA-155 for normal immune function. Science (2007) 316:608-11. doi:10.1126/science.1139253

65. Lind EF, Elford AR, Ohashi PS. micro-RNA 155 is required for optimal CD8+ T cell responses to acute viral and intracellular bacterial challenges. J Immunol (2013) 190:1210-6. doi:10.4049/jimmunol.1202700

66. Bala S, Tilahun Y, Taha O, Alao H, Kodys K, Catalano D, et al. Increased microRNA-155 expression in the serum and peripheral monocytes in chronic HCV infection. J Transl Med (2012) 10:151. doi:10.1186/1479-587610-151

67. Jablonski KA, Gaudet AD, Amici SA, Popovich PG, Guerau-de-Arellano M. Control of the inflammatory macrophage transcriptional signature by miR-155. PLoS One (2016) 11:e0159724. doi:10.1371/journal.pone.0159724

68. Staedel C, Darfeuille F. microRNAs and bacterial infection. Cell Microbiol (2013) 15:1496-507. doi:10.1111/cmi.12159

69. Furci L, Schena E, Miotto P, Cirillo DM. Alteration of human macrophages microRNA expression profile upon infection with Mycobacterium tuberculosis. Int J Mycobacteriol (2013) 2:128-34. doi:10.1016/j.ijmyco.2013. 04.006

70. Vegh P, Magee DA, Nalpas NC, Bryan K, McCabe MS, Browne JA, et al. microRNA profiling of the bovine alveolar macrophage response to Mycobacterium bovis infection suggests pathogen survival is enhanced by microRNA regulation of endocytosis and lysosome trafficking. Tuberculosis (2015) 95:60-7. doi:10.1016/j.tube.2014.10.011

71. Eulalio A, Schulte L, Vogel J. The mammalian microRNA response to bacterial infections. RNA Biol (2012) 9:742-50. doi:10.4161/rna.20018

72. Bettencourt P, Pires D, Anes E. Immunomodulating microRNAs of mycobacterial infections. Tuberculosis (Edinb) (2016) 97:1-7. doi:10.1016/ j.tube.2015.12.004

73. Wang Y, Cai Y. A survey on database resources for microRNA-disease relationships. Brief Funct Genomics (2017) (in press). doi:10.1093/bfgp/elw015

74. Contreras J, Rao DS. microRNAs in inflammation and immune responses. Leukemia (2012) 26:404-13. doi:10.1038/leu.2011.356

75. Robbins PD, Morelli AE. Regulation of immune responses by extracellular vesicles. Nat Rev Immunol (2014) 14:195-208. doi:10.1038/nri3622
76. Fernandez-Messina L, Gutierrez-Vazquez C, Rivas-Garcia E, SanchezMadrid F, de la Fuente H. Immunomodulatory role of microRNAs transferred by extracellular vesicles. Biol Cell (2015) 107:61-77. doi:10.1111/boc. 201400081

77. de Candia P, De Rosa V, Casiraghi M, Matarese G. Extracellular RNAs: a secret arm of immune system regulation. J Biol Chem (2016) 291:7221-8. doi:10.1074/jbc.R115.708842

78. Weber JA, Baxter DH, Zhang S, Huang DY, Huang KH, Lee MJ, et al. The microRNA spectrum in 12 body fluids. Clin Chem (2010) 56:1733-41. doi:10.1373/clinchem.2010.147405

79. Arroyo JD, Chevillet JR, Kroh EM, Ruf IK, Pritchard CC, Gibson DF, et al. Argonaute 2 complexes carry a population of circulating microRNAs independent of vesicles in human plasma. Proc Natl Acad Sci U S A (2011) 108:5003-8. doi:10.1073/pnas.1019055108

80. Turchinovich A, Weiz L, Langheinz A, Burwinkel B. Characterization of extracellular circulating microRNA. Nucleic Acids Res (2011) 39:7223-33. doi:10.1093/nar/gkr254

81. Zhang Y, Liu D, Chen X, Li J, Li L, Bian Z, et al. Secreted monocytic miR-150 enhances targeted endothelial cell migration. Mol Cell (2010) 39:133-44. doi:10.1016/j.molcel.2010.06.010

82. Wang K, Zhang S, Weber J, Baxter D, Galas DJ. Export of microRNAs and microRNA-protective protein by mammalian cells. Nucleic Acids Res (2010) 38:7248-59. doi:10.1093/nar/gkq601

83. Cortez MA, Bueso-Ramos C, Ferdin J, Lopez-Berestein G, Sood AK, Calin GA. microRNAs in body fluids - the mix of hormones and biomarkers. Nat Rev Clin Oncol (2011) 8:467-77. doi:10.1038/nrclinonc.2011.76

84. Mandel P, Metais P. Les acides nucléiques du plasma sanguin chez l'homme [The nucleic acids from blood plasma in humans]. C R Seances Soc Biol Fil (1948) 142:241-3.

85. Swarup V, Rajeswari MR. Circulating (cell-free) nucleic acids - a promising, non-invasive tool for early detection of several human diseases. FEBS Lett (2007) 581:795-9. doi:10.1016/j.febslet.2007.01.051

86. Chim SS, Shing TK, Hung EC, Leung TY, Lau TK, Chiu RW, et al. Detection and characterization of placental microRNAs in maternal plasma. Clin Chem (2008) 54:482-90. doi:10.1373/clinchem.2007.097972

87. Lawrie CH, Gal S, Dunlop HM, Pushkaran B, Liggins AP, Pulford K, et al. Detection of elevated levels of tumour-associated microRNAs in serum of patients with diffuse large B-cell lymphoma. Br J Haematol (2008) 141:672-5. doi:10.1111/j.1365-2141.2008.07077.x

88. Mitchell PS, Parkin RK, Kroh EM, Fritz BR, Wyman SK, PogosovaAgadjanyan EL, et al. Circulating microRNAs as stable blood-based markers for cancer detection. Proc Natl Acad Sci U S A (2008) 105:10513-8. doi:10.1073/pnas.0804549105

89. Schwarzenbach H, Nishida N, Calin GA, Pantel K. Clinical relevance of circulating cell-free microRNAs in cancer. Nat Rev Clin Oncol (2014) 11:145-56. doi:10.1038/nrclinonc.2014.5

90. Ono S, Lam S, Nagahara M, Hoon DS. Circulating microRNA biomarkers as liquid biopsy for cancer patients: pros and cons of current assays. J Clin Med (2015) 4:1890-907. doi:10.3390/jcm4101890

91. Wang J, Chen J, Sen S. microRNA as biomarkers and diagnostics. J Cell Physiol (2016) 231:25-30. doi:10.1002/jcp.25056

92. Diamandis EP. The failure of protein cancer biomarkers to reach the clinic: why, and what can be done to address the problem? BMC Med (2012) 10:87. doi:10.1186/1741-7015-10-87

93. Koberle V, Pleli T, Schmithals C, Augusto Alonso E, Haupenthal J, Bonig H, et al. Differential stability of cell-free circulating microRNAs: implications for their utilization as biomarkers. PLoS One (2013) 8:e75184. doi:10.1371/ journal.pone.0075184

94. Shaughnessy RG, Farrell D, Riepema K, Bakker D, Gordon SV. Analysis of biobanked serum from a Mycobacterium avium subsp paratuberculosis bovine infection model confirms the remarkable stability of circulating miRNA profiles and defines a bovine serum miRNA repertoire. PLoS One (2015) 10:e0145089. doi:10.1371/journal.pone.0145089

95. Unger L, Fouche N, Leeb T, Gerber V, Pacholewska A. Optimized methods for extracting circulating small RNAs from long-term stored equine samples. Acta Vet Scand (2016) 58:44. doi:10.1186/s13028-016-0224-5

96. McDonald JS, Milosevic D, Reddi HV, Grebe SK, Algeciras-Schimnich A. Analysis of circulating microRNA: preanalytical and analytical challenges. Clin Chem (2011) 57:833-40. doi:10.1373/clinchem.2010.157198 
97. Wang K, Yuan Y, Cho JH, McClarty S, Baxter D, Galas DJ. Comparing the microRNA spectrum between serum and plasma. PLoS One (2012) 7:e41561. doi:10.1371/journal.pone.0041561

98. Blondal T, Jensby Nielsen S, Baker A, Andreasen D, Mouritzen P, Wrang Teilum M, et al. Assessing sample and miRNA profile quality in serum and plasma or other biofluids. Methods (2013) 59:S1-6. doi:10.1016/ j.ymeth.2012.09.015

99. Binderup HG, Houlind K, Madsen JS, Brasen CL. Pre-storage centrifugation conditions have significant impact on measured microRNA levels in biobanked EDTA plasma samples. Biochem Biophys Rep (2016) 7:195-200. doi:10.1016/j.bbrep.2016.06.005

100. Kim DJ, Linnstaedt S, Palma J, Park JC, Ntrivalas E, Kwak-Kim JY, et al. Plasma components affect accuracy of circulating cancer-related microRNA quantitation. J Mol Diagn (2012) 14:71-80. doi:10.1016/j.jmoldx. 2011.09.002

101. Li S, Chen H, Song J, Lee C, Geng Q. Avoiding heparin inhibition in circulating microRNAs amplification. Int J Cardiol (2016) 207:92-3. doi:10.1016/ j.ijcard.2016.01.129

102. Pritchard CC, Kroh E, Wood B, Arroyo JD, Dougherty KJ, Miyaji MM, et al. Blood cell origin of circulating microRNAs: a cautionary note for cancer biomarker studies. Cancer Prev Res (Phila) (2012) 5:492-7. doi:10.1158/19406207.CAPR-11-0370

103. Kim YK, Yeo J, Kim B, Ha M, Kim VN. Short structured RNAs with low GC content are selectively lost during extraction from a small number of cells. Mol Cell (2012) 46:893-5. doi:10.1016/j.molcel.2012.05.036

104. Pritchard CC, Cheng HH, Tewari M. microRNA profiling: approaches and considerations. Nat Rev Genet (2012) 13:358-69. doi:10.1038/ $\operatorname{nrg} 3198$

105. Di Leva G, Croce CM. miRNA profiling of cancer. Curr Opin Genet Dev (2013) 23:3-11. doi:10.1016/j.gde.2013.01.004

106. Baker M. microRNA profiling: separating signal from noise. Nat Methods (2010) 7:687-92. doi:10.1038/nmeth0910-687

107. Kolbert CP, Feddersen RM, Rakhshan F, Grill DE, Simon G, Middha S, et al. Multi-platform analysis of microRNA expression measurements in RNA from fresh frozen and FFPE tissues. PLoS One (2013) 8:e52517. doi:10.1371/ journal.pone. 0052517

108. Tian T, Wang J, Zhou X. A review: microRNA detection methods. Org Biomol Chem (2015) 13:2226-38. doi:10.1039/c4ob02104e

109. Fiedler SD, Carletti MZ, Christenson LK. Quantitative RT-PCR methods for mature microRNA expression analysis. Methods Mol Biol (2010) 630:49-64. doi:10.1007/978-1-60761-629-0_4

110. Chen C, Ridzon DA, Broomer AJ, Zhou Z, Lee DH, Nguyen JT, et al. Realtime quantification of microRNAs by stem-loop RT-PCR. Nucleic Acids Res (2005) 33:e179. doi:10.1093/nar/gnil78

111. Koshkin AA, Singh SK, Nielsen P, Rajwanshi VK, Kumar R, Meldgaard M, et al. LNA (locked nucleic acids): synthesis of the adenine, cytosine, guanine, 5-methylcytosine, thymine and uracil bicyclonucleoside monomers, oligomerisation, and unprecedented nucleic acid recognition. Tetrahedron (1998) 54:3607-30. doi:10.1016/S0040-4020(98)00094-5

112. Kok MG, Halliani A, Moerland PD, Meijers JC, Creemers EE, PintoSietsma SJ. Normalization panels for the reliable quantification of circulating microRNAs by RT-qPCR. FASEB J (2015) 29:3853-62. doi:10.1096/ fj. $15-271312$

113. Schlosser K, McIntyre LA, White RJ, Stewart DJ. Customized internal reference controls for improved assessment of circulating microRNAs in disease. PLoS One (2015) 10:e0127443. doi:10.1371/journal.pone.0127443

114. Marabita F, de Candia P, Torri A, Tegner J, Abrignani S, Rossi RL. Normalization of circulating microRNA expression data obtained by quantitative real-time RT-PCR. Brief Bioinform (2016) 17:204-12. doi:10.1093/ bib/bbv056

115. Wu D, Hu Y, Tong S, Williams BR, Smyth GK, Gantier MP. The use of miRNA microarrays for the analysis of cancer samples with global miRNA decrease. RNA (2013) 19:876-88. doi:10.1261/rna.035055.112

116. Nalpas NC, Park SD, Magee DA, Taraktsoglou M, Browne JA, Conlon KM, et al. Whole-transcriptome, high-throughput RNA sequence analysis of the bovine macrophage response to Mycobacterium bovis infection in vitro. $B M C$ Genomics (2013) 14:230. doi:10.1186/1471-2164-14-230

117. McLoughlin KE, Nalpas NC, Rue-Albrecht K, Browne JA, Magee DA, Killick $\mathrm{KE}$, et al. RNA-seq transcriptional profiling of peripheral blood leukocytes from cattle infected with Mycobacterium bovis. Front Immunol (2014) 5:396. doi:10.3389/fimmu.2014.00396

118. Geiss GK, Bumgarner RE, Birditt B, Dahl T, Dowidar N, Dunaway DL, et al. Direct multiplexed measurement of gene expression with color-coded probe pairs. Nat Biotechnol (2008) 26:317-25. doi:10.1038/nbt1385

119. Wang RY, Weng KF, Huang YC, Chen CJ. Elevated expression of circulating miR876-5p is a specific response to severe EV71 infections. Sci Rep (2016) 6:24149. doi:10.1038/srep24149

120. Yamamoto M, Singh A, Ruan J, Gauvreau GM, O’Byrne PM, Carlsten CR, et al. Decreased miR-192 expression in peripheral blood of asthmatic individuals undergoing an allergen inhalation challenge. BMC Genomics (2012) 13:655. doi:10.1186/1471-2164-13-655

121. Vikram A, Kim YR, Kumar S, Li Q, Kassan M, Jacobs JS, et al. Vascular microRNA-204 is remotely governed by the microbiome and impairs endothelium-dependent vasorelaxation by downregulating Sirtuin1. Nat Commun (2016) 7:12565. doi:10.1038/ncomms12565

122. Keller A, Leidinger P, Bauer A, Elsharawy A, Haas J, Backes C, et al. Toward the blood-borne miRNome of human diseases. Nat Methods (2011) 8:841-3. doi:10.1038/nmeth.1682

123. Li N, You X, Chen T, Mackowiak SD, Friedlander MR, Weigt M, et al. Global profiling of miRNAs and the hairpin precursors: insights into miRNA processing and novel miRNA discovery. Nucleic Acids Res (2013) 41:3619-34. doi:10.1093/nar/gkt072

124. Siddle KJ, Tailleux L, Deschamps M, Loh YH, Deluen C, Gicquel B, et al. Bacterial infection drives the expression dynamics of microRNAs and their isomiRs. PLoS Genet (2015) 11:e1005064. doi:10.1371/journal.pgen. 1005064

125. Huang HC, Niu Y, Qin LX. Differential expression analysis for RNA-seq: an overview of statistical methods and computational software. Cancer Inform (2015) 14:57-67. doi:10.4137/CIN.S21631

126. Ziemann M, Kaspi A, El-Osta A. Evaluation of microRNA alignment techniques. RNA (2016) 22:1120-38. doi:10.1261/rna.055509.115

127. Raabe CA, Tang TH, Brosius J, Rozhdestvensky TS. Biases in small RNA deep sequencing data. Nucleic Acids Res (2014) 42:1414-26. doi:10.1093/nar/ gkt1021

128. Baroin-Tourancheau A, Benigni X, Doubi-Kadmiri S, Taouis M, Amar L. Lessons from microRNA sequencing using Illumina technology. Adv Biosci Biotechnol (2016) 07:319-28. doi:10.4236/abb.2016.77030

129. Graybill RM, Bailey RC. Emerging biosensing approaches for microRNA analysis. Anal Chem (2016) 88:431-50. doi:10.1021/acs.analchem.5b04679

130. Benz F, Roderburg C, Vargas Cardenas D, Vucur M, Gautheron J, Koch A, et al. U6 is unsuitable for normalization of serum miRNA levels in patients with sepsis or liver fibrosis. Exp Mol Med (2013) 45:e42. doi:10.1038/ emm.2013.81

131. D'Haene B, Mestdagh P, Hellemans J, Vandesompele J. miRNA expression profiling: from reference genes to global mean normalization. Methods $\mathrm{Mol}$ Biol (2012) 822:261-72. doi:10.1007/978-1-61779-427-8_18

132. Reid G, Kirschner MB, van Zandwijk N. Circulating microRNAs: association with disease and potential use as biomarkers. Crit Rev Oncol Hematol (2011) 80:193-208. doi:10.1016/j.critrevonc.2010.11.004

133. Tang G, Shen X, Lv K, Wu Y, Bi J, Shen Q. Different normalization strategies might cause inconsistent variation in circulating microRNAs in patients with hepatocellular carcinoma. Med Sci Monit (2015) 21:617-24. doi:10.12659/ MSM. 891028

134. Mestdagh P, Van Vlierberghe P, De Weer A, Muth D, Westermann F, Speleman F, et al. A novel and universal method for microRNA RT-qPCR data normalization. Genome Biol (2009) 10:R64. doi:10.1186/gb-2009-10-6-r64

135. Robinson MD, Oshlack A. A scaling normalization method for differential expression analysis of RNA-seq data. Genome Biol (2010) 11:R25. doi:10.1186/ gb-2010-11-3-r25

136. Bullard JH, Purdom E, Hansen KD, Dudoit S. Evaluation of statistical methods for normalization and differential expression in mRNA-seq experiments. BMC Bioinformatics (2010) 11:94. doi:10.1186/1471-210511-94

137. Tam S, Tsao MS, McPherson JD. Optimization of miRNA-seq data preprocessing. Brief Bioinform (2015) 16:950-63. doi:10.1093/bib/bbv019

138. Garmire LX, Subramaniam S. Evaluation of normalization methods in mammalian microRNA-Seq data. RNA (2012) 18:1279-88. doi:10.1261/ rna.030916.111 
139. Cleveland WS, Devlin SJ. Locally weighted regression: an approach to regression analysis by local fitting. J Am Stat Assoc (1988) 83:596. doi:10.1080/ 01621459.1988.10478639

140. Jain N, Thatte J, Braciale T, Ley K, O'Connell M, Lee JK. Local-pooled-error test for identifying differentially expressed genes with a small number of replicated microarrays. Bioinformatics (2003) 19:1945-51. doi:10.1093/ bioinformatics/btg264

141. Bolstad BM, Irizarry RA, Astrand M, Speed TP. A comparison of normalization methods for high density oligonucleotide array data based on variance and bias. Bioinformatics (2003) 19:185-93. doi:10.1093/bioinformatics/ 19.2.185

142. Dillies MA, Rau A, Aubert J, Hennequet-Antier C, Jeanmougin M, Servant $\mathrm{N}$, et al. A comprehensive evaluation of normalization methods for Illumina high-throughput RNA sequencing data analysis. Brief Bioinform (2013) 14:671-83. doi:10.1093/bib/bbs046

143. Zhou X, Oshlack A, Robinson MD. miRNA-Seq normalization comparisons need improvement. RNA (2013) 19:733-4. doi:10.1261/rna.037895.112

144. World Health Organization. Global Tuberculosis Report 2015. Geneva: World Health Organization (2015).

145. Leylabadlo HE, Kafil HS, Yousefi M, Aghazadeh M, Asgharzadeh M. Pulmonary tuberculosis diagnosis: where we are? Tuberc Respir Dis (Seoul) (2016) 79:134-42. doi:10.4046/trd.2016.79.3.134

146. Pai M, Schito M. Tuberculosis diagnostics in 2015: landscape, priorities, needs, and prospects. J Infect Dis (2015) 211(Suppl 2):S21-8. doi:10.1093/ infdis/jiu803

147. Fu Y, Yi Z, Wu X, Li J, Xu F. Circulating microRNAs in patients with active pulmonary tuberculosis. J Clin Microbiol (2011) 49:4246-51. doi:10.1128/ JCM.05459-11

148. Yi Z, Fu Y, Ji R, Li R, Guan Z. Altered microRNA signatures in sputum of patients with active pulmonary tuberculosis. PLoS One (2012) 7:e43184. doi:10.1371/journal.pone.0043184

149. Qi Y, Cui L, Ge Y, Shi Z, Zhao K, Guo X, et al. Altered serum microRNAs as biomarkers for the early diagnosis of pulmonary tuberculosis infection. $B M C$ Infect Dis (2012) 12:384. doi:10.1186/1471-2334-12-384

150. Abd-El-Fattah AA, Sadik NA, Shaker OG, Aboulftouh ML. Differential microRNAs expression in serum of patients with lung cancer, pulmonary tuberculosis, and pneumonia. Cell Biochem Biophys (2013) 67:875-84. doi:10.1007/s12013-013-9575-y

151. Zhang X, Guo J, Fan S, Li Y, Wei L, Yang X, et al. Screening and identification of six serum microRNAs as novel potential combination biomarkers for pulmonary tuberculosis diagnosis. PLoS One (2013) 8:e81076. doi:10.1371/ journal.pone. 0081076

152. Zhang H, Sun Z, Wei W, Liu Z, Fleming J, Zhang S, et al. Identification of serum microRNA biomarkers for tuberculosis using RNA-seq. PLoS One (2014) 9:e88909. doi:10.1371/journal.pone.0088909

153. Vivier E, Tomasello E, Baratin M, Walzer T, Ugolini S. Functions of natural killer cells. Nat Immunol (2008) 9:503-10. doi:10.1038/ni1582

154. Zhang C, Xi X, Wang Q, Jiao J, Zhang L, Zhao H, et al. The association between serum miR-155 and natural killer cells from tuberculosis patients. Int J Clin Exp Med (2015) 8:9168-72.

155. Rittirsch D, Flierl MA, Ward PA. Harmful molecular mechanisms in sepsis. Nat Rev Immunol (2008) 8:776-87. doi:10.1038/nri2402

156. Parlato M, Cavaillon JM. Host response biomarkers in the diagnosis of sepsis: a general overview. Methods Mol Biol (2015) 1237:149-211. doi:10.1007/ 978-1-4939-1776-1_15

157. Benz F, Roy S, Trautwein C, Roderburg C, Luedde T. Circulating microRNAs as biomarkers for sepsis. Int J Mol Sci (2016) 17:E78. doi:10.3390/ ijms17010078

158. Vasilescu C, Rossi S, Shimizu M, Tudor S, Veronese A, Ferracin M, et al. microRNA fingerprints identify miR-150 as a plasma prognostic marker in patients with sepsis. PLoS One (2009) 4:e7405. doi:10.1371/journal. pone. 0007405

159. Puskarich MA, Nandi U, Shapiro NI, Trzeciak S, Kline JA, Jones AE. Detection of microRNAs in patients with sepsis. J Acute Dis (2015) 4:101-6. doi:10.1016/s2221-6189(15)30017-2

160. Roderburg C, Luedde M, Vargas Cardenas D, Vucur M, Scholten D, Frey N, et al. Circulating microRNA-150 serum levels predict survival in patients with critical illness and sepsis. PLoS One (2013) 8:e54612. doi:10.1371/ journal.pone. 0054612
161. Wang JF, Yu ML, Yu G, Bian JJ, Deng XM, Wan XJ, et al. Serum miR-146a and miR-223 as potential new biomarkers for sepsis. Biochem Biophys Res Commun (2010) 394:184-8. doi:10.1016/j.bbrc.2010.02.145

162. Wang L, Wang HC, Chen C, Zeng J, Wang Q, Zheng L, et al. Differential expression of plasma miR-146a in sepsis patients compared with nonsepsis-SIRS patients. Exp Ther Med (2013) 5:1101-4. doi:10.3892/etm. 2013.937

163. Benz F, Tacke F, Luedde M, Trautwein C, Luedde T, Koch A, et al. Circulating microRNA-223 serum levels do not predict sepsis or survival in patients with critical illness. Dis Markers (2015) 2015:384208. doi:10.1155/2015/384208

164. Tacke F, Roderburg C, Benz F, Cardenas DV, Luedde M, Hippe HJ, et al. Levels of circulating miR-133a are elevated in sepsis and predict mortality in critically ill patients. Crit Care Med (2014) 42:1096-104. doi:10.1097/ CCM.0000000000000131

165. Roderburg C, Benz F, Vargas Cardenas D, Koch A, Janssen J, Vucur M, et al. Elevated miR-122 serum levels are an independent marker of liver injury in inflammatory diseases. Liver Int (2015) 35:1172-84. doi:10.1111/ liv. 12627

166. Wang H, Meng K, Chen W, Feng D, Jia Y, Xie L. Serum miR-574-5p: a prognostic predictor of sepsis patients. Shock (2012) 37:263-7. doi:10.1097/ SHK.0b013e318241baf8

167. Wang H, Zhang P, Chen W, Feng D, Jia Y, Xie L. Serum microRNA signatures identified by Solexa sequencing predict sepsis patients' mortality: a prospective observational study. PLoS One (2012) 7:e38885. doi:10.1371/journal. pone. 0038885

168. World Health Organization. Hepatitis B Fact Sheet. (2016). Available from: http://www.who.int/mediacentre/factsheets/fs204/en

169. Ott JJ, Stevens GA, Groeger J, Wiersma ST. Global epidemiology of hepatitis B virus infection: new estimates of age-specific HBsAg seroprevalence and endemicity. Vaccine (2012) 30:2212-9. doi:10.1016/j.vaccine. 2011.12.116

170. Ji F, Yang B, Peng X, Ding H, You H, Tien P. Circulating microRNAs in hepatitis B virus-infected patients. J Viral Hepat (2011) 18:e242-51. doi:10.1111/j.1365-2893.2011.01443.x

171. Song G, Jia H, Xu H, Liu W, Zhu H, Li S, et al. Studying the association of microRNA-210 level with chronic hepatitis B progression. J Viral Hepat (2014) 21:272-80. doi:10.1111/jvh.12138

172. Wang JY, Mao RC, Zhang YM, Zhang YJ, Liu HY, Qin YL, et al. Serum microRNA-124 is a novel biomarker for liver necroinflammation in patients with chronic hepatitis B virus infection. J Viral Hepat (2015) 22:128-36. doi:10.1111/jvh.12284

173. Zhang Q, Xu M, Qu Y, Li Z, Zhang Q, Cai X, et al. Analysis of the differential expression of circulating microRNAs during the progression of hepatic fibrosis in patients with chronic hepatitis B virus infection. Mol Med Rep (2015) 12:5647-54. doi:10.3892/mmr.2015.4221

174. Zhou J, Yu L, Gao X, Hu J, Wang J, Dai Z, et al. Plasma microRNA panel to diagnose hepatitis B virus-related hepatocellular carcinoma. J Clin Oncol (2011) 29:4781-8. doi:10.1200/JCO.2011.38.2697

175. Winther TN, Jacobsen KS, Mirza AH, Heiberg IL, Bang-Berthelsen CH, Pociot F, et al. Circulating microRNAs in plasma of hepatitis B e antigen positive children reveal liver-specific target genes. Int J Hepatol (2014) 2014:791045. doi:10.1155/2014/791045

176. Qi P, Cheng SQ, Wang H, Li N, Chen YF, Gao CF. Serum microRNAs as biomarkers for hepatocellular carcinoma in Chinese patients with chronic hepatitis B virus infection. PLoS One (2011) 6:e28486. doi:10.1371/journal. pone.0028486

177. Tan Y, Ge G, Pan T, Wen D, Chen L, Yu X, et al. A serum microRNA panel as potential biomarkers for hepatocellular carcinoma related with hepatitis B virus. PLoS One (2014) 9:e107986. doi:10.1371/journal.pone. 0107986

178. Sohn W, Kim J, Kang SH, Yang SR, Cho JY, Cho HC, et al. Serum exosomal microRNAs as novel biomarkers for hepatocellular carcinoma. Exp Mol Med (2015) 47:e184. doi:10.1038/emm.2015.68

179. Yu F, Lu Z, Chen B, Dong P, Zheng J. microRNA-150: a promising novel biomarker for hepatitis B virus-related hepatocellular carcinoma. Diagn Pathol (2015) 10:129. doi:10.1186/s13000-015-0369-y

180. Li L, Guo Z, Wang J, Mao Y, Gao Q. Serum miR-18a: a potential marker for hepatitis B virus-related hepatocellular carcinoma screening. Dig Dis Sci (2012) 57:2910-6. doi:10.1007/s10620-012-2317-y 
181. Zhang Y, Jia Y, Zheng R, Guo Y, Wang Y, Guo H, et al. Plasma microRNA-122 as a biomarker for viral-, alcohol-, and chemical-related hepatic diseases. Clin Chem (2010) 56:1830-8. doi:10.1373/clinchem.2010.147850

182. Zhang X, Zhang Z, Dai F, Shi B, Chen L, Zhang X, et al. Comparison of circulating, hepatocyte specific messenger RNA and microRNA as biomarkers for chronic hepatitis B and C. PLoS One (2014) 9:e92112. doi:10.1371/journal. pone.0092112

183. Xu J, Wu C, Che X, Wang L, Yu D, Zhang T, et al. Circulating microRNAs, miR-21, miR-122, and miR-223, in patients with hepatocellular carcinoma or chronic hepatitis. Mol Carcinog (2011) 50:136-42. doi:10.1002/ mc. 20712

184. Zhang H, Li QY, Guo ZZ, Guan Y, Du J, Lu YY, et al. Serum levels of microRNAs can specifically predict liver injury of chronic hepatitis B. World J Gastroenterol (2012) 18:5188-96. doi:10.3748/wjg.v18.i37.5188

185. Arataki K, Hayes CN, Akamatsu S, Akiyama R, Abe H, Tsuge M, et al. Circulating microRNA-22 correlates with microRNA-122 and represents viral replication and liver injury in patients with chronic hepatitis B. J Med Virol (2013) 85:789-98. doi:10.1002/jmv.23540

186. Waidmann O, Bihrer V, Pleli T, Farnik H, Berger A, Zeuzem S, et al. Serum microRNA-122 levels in different groups of patients with chronic hepatitis B virus infection. J Viral Hepat (2012) 19:e58-65. doi:10.1111/ j.1365-2893.2011.01536.x

187. Winther TN, Bang-Berthelsen CH, Heiberg IL, Pociot F, Hogh B. Differential plasma microRNA profiles in HBeAg positive and HBeAg negative children with chronic hepatitis B. PLoS One (2013) 8:e58236. doi:10.1371/journal. pone. 0058236

188. Winther TN, Heiberg IL, Bang-Berthelsen CH, Pociot F, Hogh B. Hepatitis B surface antigen quantity positively correlates with plasma levels of microRNAs differentially expressed in immunological phases of chronic hepatitis B in children. PLoS One (2013) 8:e80384. doi:10.1371/journal.pone. 0080384

189. Chen Y, Li L, Zhou Z, Wang N, Zhang CY, Zen K. A pilot study of serum microRNA signatures as a novel biomarker for occult hepatitis B virus infection. Med Microbiol Immunol (2012) 201:389-95. doi:10.1007/s00430011-0223-0

190. Li LM, Hu ZB, Zhou ZX, Chen X, Liu FY, Zhang JF, et al. Serum microRNA profiles serve as novel biomarkers for HBV infection and diagnosis of HBVpositive hepatocarcinoma. Cancer Res (2010) 70:9798-807. doi:10.1158/00085472.CAN-10-1001

191. Jopling CL, Yi M, Lancaster AM, Lemon SM, Sarnow P. Modulation of hepatitis C virus RNA abundance by a liver-specific microRNA. Science (2005) 309:1577-81. doi:10.1126/science.1113329

192. Bihrer V, Friedrich-Rust M, Kronenberger B, Forestier N, Haupenthal J, Shi Y, et al. Serum miR-122 as a biomarker of necroinflammation in patients with chronic hepatitis C virus infection. Am J Gastroenterol (2011) 106:1663-9. doi:10.1038/ajg.2011.161

193. Cermelli S, Ruggieri A, Marrero JA, Ioannou GN, Beretta L. Circulating microRNAs in patients with chronic hepatitis $\mathrm{C}$ and non-alcoholic fatty liver disease. PLoS One (2011) 6:e23937. doi:10.1371/journal.pone. 0023937

194. van der Meer AJ, Farid WR, Sonneveld MJ, de Ruiter PE, Boonstra A, van Vuuren AJ, et al. Sensitive detection of hepatocellular injury in chronic hepatitis C patients with circulating hepatocyte-derived microRNA-122. J Viral Hepat (2013) 20:158-66. doi:10.1111/jvh.12001

195. Wang JH, Jiang D, Rao HY, Zhao JM, Wang Y, Wei L. Absolute quantification of serum microRNA-122 and its correlation with liver inflammation grade and serum alanine aminotransferase in chronic hepatitis $\mathrm{C}$ patients. Int J Infect Dis (2015) 30:52-6. doi:10.1016/j.ijid.2014.09.020

196. Zhang S, Ouyang X, Jiang X, Gu D, Lin Y, Kong SK, et al. Dysregulated serum microRNA expression profile and potential biomarkers in hepatitis C virus-infected patients. Int J Med Sci (2015) 12:590-8. doi:10.7150/ ijms. 11525

197. Trebicka J, Anadol E, Elfimova N, Strack I, Roggendorf M, Viazov S, et al. Hepatic and serum levels of miR-122 after chronic HCV-induced fibrosis. J Hepatol (2013) 58:234-9. doi:10.1016/j.jhep.2012.10.015

198. Su TH, Liu CH, Liu CJ, Chen CL, Ting TT, Tseng TC, et al. Serum microRNA-122 level correlates with virologic responses to pegylated interferon therapy in chronic hepatitis C. Proc Natl Acad Sci U S A (2013) 110:7844-9. doi:10.1073/pnas.1306138110
199. Estrabaud E, Lapalus M, Broet P, Appourchaux K, De Muynck S, Lada O, et al. Reduction of microRNA 122 expression in IFNL3 CT/TT carriers and during progression of fibrosis in patients with chronic hepatitis C. J Virol (2014) 88:6394-402. doi:10.1128/JVI.00016-14

200. El-Diwany R, Wasilewski LN, Witwer KW, Bailey JR, Page K, Ray SC, et al. Acute hepatitis $\mathrm{C}$ virus infection induces consistent changes in circulating microRNAs that are associated with nonlytic hepatocyte release. J Virol (2015) 89:9454-64. doi:10.1128/JVI.00955-15

201. Roderburg C, Mollnow T, Bongaerts B, Elfimova N, Vargas Cardenas D, Berger $\mathrm{K}$, et al. Micro-RNA profiling in human serum reveals compartment-specific roles of miR-571 and miR-652 in liver cirrhosis. PLoS One (2012) 7:e32999. doi:10.1371/journal.pone.0032999

202. Shrivastava S, Petrone J, Steele R, Lauer GM, Di Bisceglie AM, Ray RB. Up-regulation of circulating miR-20a is correlated with hepatitis C virus-mediated liver disease progression. Hepatology (2013) 58:863-71. doi:10.1002/ hep. 26296

203. Shwetha S, Gouthamchandra K, Chandra M, Ravishankar B, Khaja MN, Das S. Circulating miRNA profile in HCV infected serum: novel insight into pathogenesis. Sci Rep (2013) 3:1555. doi:10.1038/srep01555

204. El-Abd NE, Fawzy NA, El-Sheikh SM, Soliman ME. Circulating miRNA122, miRNA-199a, and miRNA-16 as biomarkers for early detection of hepatocellular carcinoma in Egyptian patients with chronic hepatitis C virus infection. Mol Diagn Ther (2015) 19:213-20. doi:10.1007/s40291-0150148-1

205. Qu KZ, Zhang K, Li H, Afdhal NH, Albitar M. Circulating microRNAs as biomarkers for hepatocellular carcinoma. J Clin Gastroenterol (2011) 45:355-60. doi:10.1097/MCG.0b013e3181f18ac2

206. Bihrer V, Waidmann O, Friedrich-Rust M, Forestier N, Susser S, Haupenthal J, et al. Serum microRNA-21 as marker for necroinflammation in hepatitis C patients with and without hepatocellular carcinoma. PLoS One (2011) 6:e26971. doi:10.1371/journal.pone.0026971

207. Tomimaru Y, Eguchi H, Nagano H, Wada H, Kobayashi S, Marubashi $\mathrm{S}$, et al. Circulating microRNA-21 as a novel biomarker for hepatocellular carcinoma. J Hepatol (2012) 56:167-75. doi:10.1016/j.jhep.2011. 04.026

208. Ge Y, Zhao K, Qi Y, Min X, Shi Z, Qi X, et al. Serum microRNA expression profile as a biomarker for the diagnosis of pertussis. Mol Biol Rep (2013) 40:1325-32. doi:10.1007/s11033-012-2176-9

209. Sanmarti M, Ibanez L, Huertas S, Badenes D, Dalmau D, Slevin M, et al. HIV-associated neurocognitive disorders. J Mol Psychiatry (2014) 2:2. doi:10.1186/2049-9256-2-2

210. Zayyad Z, Spudich S. Neuropathogenesis of HIV: from initial neuroinvasion to HIV-associated neurocognitive disorder (HAND). Curr HIV/AIDS Rep (2015) 12:16-24. doi:10.1007/s11904-014-0255-3

211. Kadri F, LaPlante A, De Luca M, Doyle L, Velasco-Gonzalez C, Patterson JR, et al. Defining plasma microRNAs associated with cognitive impairment in HIV-infected patients. J Cell Physiol (2016) 231:829-36. doi:10.1002/ jcp. 25131

212. Witwer KW, Sarbanes SL, Liu J, Clements JE. A plasma microRNA signature of acute lentiviral infection: biomarkers of central nervous system disease. AIDS (2011) 25:2057-67. doi:10.1097/QAD.0b013e 32834b95bf

213. Pacifici M, Delbue S, Ferrante P, Jeansonne D, Kadri F, Nelson S, et al. Cerebrospinal fluid miRNA profile in HIV-encephalitis. J Cell Physiol (2013) 228:1070-5. doi:10.1002/jcp.24254

214. Ding NZ, Wang XM, Sun SW, Song Q, Li SN, He CQ. Appearance of mosaic enterovirus 71 in the 2008 outbreak of China. Virus Res (2009) 145:157-61. doi:10.1016/j.virusres.2009.06.006

215. Cui L, Qi Y, Li H, Ge Y, Zhao K, Qi X, et al. Serum microRNA expression profile distinguishes enterovirus 71 and coxsackievirus 16 infections in patients with hand-foot-and-mouth disease. PLoS One (2011) 6:e27071. doi:10.1371/ journal.pone.0027071

216. Jia HL, He CH, Wang ZY, Xu YF, Yin GQ, Mao LJ, et al. microRNA expression profile in exosome discriminates extremely severe infections from mild infections for hand, foot and mouth disease. BMC Infect Dis (2014) 14:506. doi:10.1186/1471-2334-14-506

217. Qi Y, Zhu Z, Shi Z, Ge Y, Zhao K, Zhou M, et al. Dysregulated microRNA expression in serum of non-vaccinated children with varicella. Viruses (2014) 6:1823-36. doi:10.3390/v6041823 
218. Tambyah PA, Sepramaniam S, Mohamed Ali J, Chai SC, Swaminathan P, Armugam A, et al. microRNAs in circulation are altered in response to influenza A virus infection in humans. PLoS One (2013) 8:e76811. doi:10.1371/ journal.pone.0076811

219. Moran J, Ramirez-Martinez G, Jimenez-Alvarez L, Cruz A, Perez-Patrigeon S, Hidalgo A, et al. Circulating levels of miR-150 are associated with poorer outcomes of A/H1N1 infection. Exp Mol Pathol (2015) 99:253-61. doi:10.1016/j.yexmp.2015.07.001

220. Zhu Z, Qi Y, Ge A, Zhu Y, Xu K, Ji H, et al. Comprehensive characterization of serum microRNA profile in response to the emerging avian influenza $A$ (H7N9) virus infection in humans. Viruses (2014) 6:1525-39. doi:10.3390/ v6041525

221. Fabres-Klein MH, Aguilar AP, Silva MP, Silva DM, Ribon AO. Moving towards the immunodiagnosis of staphylococcal intramammary infections. Eur J Clin Microbiol Infect Dis (2014) 33:2095-104. doi:10.1007/s10096014-2181-0

222. Sun J, Aswath K, Schroeder SG, Lippolis JD, Reinhardt TA, Sonstegard TS. microRNA expression profiles of bovine milk exosomes in response to Staphylococcus aureus infection. BMC Genomics (2015) 16:806. doi:10.1186/ s12864-015-2044-9
223. Farrell D, Shaughnessy RG, Britton L, MacHugh DE, Markey B, Gordon SV The identification of circulating miRNA in bovine serum and their potential as novel biomarkers of early Mycobacterium avium subsp paratuberculosis infection. PLoS One (2015) 10:e0134310. doi:10.1371/journal.pone.0134310

224. Casas E, Cai G, Kuehn LA, Register KB, McDaneld TG, Neill JD Association of microRNAs with antibody response to Mycoplasma bovis in beef cattle. PLoS One (2016) 11:e0161651. doi:10.1371/journal.pone. 0161651

Conflict of Interest Statement: The authors declare that the research was conducted in the absence of any commercial or financial relationships that could be construed as a potential conflict of interest.

Copyright (c) 2017 Correia, Nalpas, McLoughlin, Browne, Gordon, MacHugh and Shaughnessy. This is an open-access article distributed under the terms of the Creative Commons Attribution License (CC BY). The use, distribution or reproduction in other forums is permitted, provided the original author(s) or licensor are credited and that the original publication in this journal is cited, in accordance with accepted academic practice. No use, distribution or reproduction is permitted which does not comply with these terms. 